\title{
Competing sexual-asexual generic names in Agaricomycotina (Basidiomycota) with recommendations for use
}

Joost A. Stalpers ${ }^{1}$, Scott A. Redhead ${ }^{2}$, Tom W. May ${ }^{3}$, Amy Y. Rossman ${ }^{4 *}$, Jo Anne Crouch ${ }^{5}$, Marc A. Cubeta ${ }^{6}$, Yu-Cheng Dai ${ }^{7}$, Roland Kirschner ${ }^{8}$, Gitta Jutta Langer ${ }^{9}$, Karl-Henrik Larsson ${ }^{10}$, Jonathan Mack ${ }^{2}$, Lorelei L. Norvell ${ }^{11}$, Franz Oberwinkler ${ }^{12}$, Viktor Papp ${ }^{13}$, Peter Roberts ${ }^{14}$, Mario Rajchenberg ${ }^{15,16}$, Keith A. Seifert ${ }^{17}$ and R. Greg Thorn ${ }^{18}$

\begin{abstract}
With the change to one scientific name for fungal taxa, generic names typified by species with sexual or asexual morph types are being evaluated to determine which names represent the same genus and thus compete for use. In this paper generic names of the Agaricomycotina (Basidiomycota) were evaluated to determine synonymy based on their type. Forty-seven sets of sexually and asexually typified names were determined to be congeneric and recommendations are made for which generic name to use. In most cases the principle of priority is followed. However, 16 generic names are recommended for use that do not have priority and thus need to be protected: Aleurocystis over Matula; Armillaria over Acurtis and Rhizomorpha; Asterophora over Ugola; Botryobasidium over Acladium, Allescheriella, Alysidium, Haplotrichum, Physospora, and Sporocephalium; Coprinellus over Ozonium; Coprinopsis over Rhacophyllus; Dendrocollybia over Sclerostilbum and Tilachlidiopsis; Diacanthodes over Bornetina; Echinoporia over Echinodia; Neolentinus over Digitellus; Postia over Ptychogaster; Riopa over Sporotrichum; Scytinostroma over Artocreas, Michenera, and Stereofomes; Tulasnella over Hormomyces; Typhula over Sclerotium; and Wolfiporia over Gemmularia and Pachyma. Nine species names are proposed for protection: Botryobasidium aureum, B. conspersum, B. croceum, B. simile, Pellicularia lembosporum (syn. B. lembosporum), Phanerochaete chrysosporium, Polyporus metamorphosus (syn. Riopa metamorphosa), Polyporus mylittae (syn. Laccocephalum mylittae), and Polyporus ptychogaster (syn. Postia ptychogaster). Two families are proposed for protection: Psathyrellaceae and Typhulaceae. Three new species names and 30 new combinations are established, and one lectotype is designated.
\end{abstract}

Keywords: Basidiomycetes, Dual nomenclature, Pleomorphic fungi, Taxonomy, Unit nomenclature, New taxa

\section{INTRODUCTION}

With the change to one scientific name for fungal taxa in accordance with the International Code of Nomenclature for algae, fungi, and plants (McNeill et al. 2012; Turland et al. 2018), there is a need to determine which generic name should be applied when two or more generic names typified by types representing different

\footnotetext{
* Correspondence: amydianer@yahoo.com

Franz Oberwinkler is deceased.

${ }^{4}$ Department of Botany and Plant Pathology, Oregon State University, Corvallis, OR 97331, USA

Full list of author information is available at the end of the article
}

morphs are congeneric. Formal recommendations about which generic name to use have been made by specialized Subcommissions or Working Groups (WG) of the International Commission for the Taxonomy of Fungi (ICTF) as discussed by May (2017). A number of publications have recommended generic names for use in major groups of Ascomycota, including Sordariomycetes such as Diaporthales (Rossman et al. 2015a), Hypocreales (Rossman et al. 2013; Quandt et al. 2014; Kepler et al. 2017), Magnaporthales (Zhang et al. 2016), Microascales and Ophiostomatales (De Beer et al. 2013), Xylariaceae (Stadler et al. 2013) and remaining Sordariomycetes

(c) The Author(s). 2021 Open Access This article is licensed under a Creative Commons Attribution 4.0 International License, which permits use, sharing, adaptation, distribution and reproduction in any medium or format, as long as you give appropriate credit to the original author(s) and the source, provide a link to the Creative Commons licence, and indicate if changes were made. The images or other third party material in this article are included in the article's Creative Commons licence, unless indicated otherwise in a credit line to the material. If material is not included in the article's Creative Commons licence and your intended use is not permitted by statutory regulation or exceeds the permitted use, you will need to obtain permission directly from the copyright holder. To view a copy of this licence, visit http://creativecommons.org/licenses/by/4.0/. 
(Réblová et al. 2016), as well as Dothideomycetes (Rossman et al. 2015b), Eurotiales (Samson et al. 2014; Visagie et al. 2014), Leotiomycetes including Erysiphales (Braun 2013; Johnston et al. 2014), Pezizomycetes (Healy et al. 2016), yeast fungi (Daniel et al. 2014), and overlooked generic names in the Ascomycota (Rossman et al. 2016a). Within the Basidiomycota a paper on the Pucciniomycotina and Ustilaginomycotina has been published (Aime et al. 2018). Where recommended names do not follow the principle of priority, such names need to be confirmed for protection by the Nomenclature Committee for Fungi (NCF) appointed by the International Mycological Congress and ultimately by the General Committee on Nomenclature appointed by the International Botanical Congress. Names approved so far by the NCF have been compiled by May (2017). Once approved, protected names appear in the on-line Appendix to the International Code of Nomenclature for algae, fungi, and plants (Wiersema et al. 2020).

Generic names of Agaricomycotina representing sexually and asexually typified genera that compete for use have been evaluated by the Homobasidiomycetes WG of the ICTF**. The original members of this group were assembled prior to compilation of the list of names needing assessment and once the list was prepared, additional mycologists who have an interest in the nomenclature of this group were involved, leading to the recommendations made herein about which generic name to use. The comprehensive list of sexual-asexual generic names by Wijayawardene et al. (2012) was used as the initial starting point for determining which generic names in the Agaricomycotina compete for use. Citations for generic names and their types are based on Index Fungorum (Kirk 2020). Each set of generic names was evaluated using the current literature about the phylogenetic placement of their types to determine if the names are congeneric. A recommendation for use is presented based on consideration of such factors as priority, number of species, required name changes, and frequency of citations in the literature based primarily on Google Scholar searches (GSS). Because there are relatively few competing generic names, they are listed in alphabetical order rather than by fungal order ${ }^{1}$.

Forty-seven sets of generic names were identified and evaluated. Details about each set of generic names and the basis for each decision are presented below with an $\mathbf{S}$ indicating a sexually typified name, an $\mathbf{A}$ indicating an asexually typified name, and $\mathbf{A} / \mathbf{S}$ indicating either ambiguity or both. The citation for each generic name, their types, accepted name of type, and action required are

\footnotetext{
1*: ICTF Homobasidiomycetes WG initial membership: Co-conveners Tom May \& Scott Redhead, Members Nico Dam, Ursula Eberhardt, Karl-Henrik Larsson, Ludmila Marvanová, Luis Morgado, Bernard Moyersoen, Lorelei Norvell, Manon Neilen, Joost Stalpers, and Benjamin Stielow.
}

listed in Table 1. Many generic names recommended for use have priority by date with relatively few or no name changes required. However, 16 generic names recommended for use do not have priority and are thus recommended for protection: Aleurocystis over Matula; Armillaria over Acurtis and Rhizomorpha; Asterophora over Ugola; Botryobasidium over Acladium, Allescheriella, Alysidium, Haplotrichum, Physospora, and Sporocephalium; Coprinellus over Ozonium; Coprinopsis over Rhacophyllus; Dendrocollybia over Sclerostilbum and Tilachlidiopsis; Diacanthodes over Bornetina; Echinoporia over Echinodia; Neolentinus over Digitellus; Postia over Ptychogaster; Riopa over Sporotrichum; Scytinostroma over Artocreas, Michenera, and Stereofomes; Tulasnella over Hormomyces; Typhula over Sclerotium; and Wolfiporia over Gemmularia and Pachyma. In addition, nine specific names are proposed for protection: Botryobasidium aureum, B. conspersum, B. croceum, B. simile, Pellicularia lembosporum (syn. B. lembosporum), Phanerochaete chrysosporium, Polyporus metamorphosus (Riopa metamorphosa), P. mylittae (Laccocephalum mylittae) and P. ptychogaster (Postia ptychogaster) as listed in Table 2. Two family names are proposed for protection: Psathyrellaceae over Zerovaemycetaceae and Typhulaceae over Sclerotiaceae as listed in Table 3. Three new species names and 30 new combinations are established and one lectotype is designated.

\section{GENERIC AND FAMILY NAMES RECOMMENDED FOR USE IN AGARICOMYCOTINA}

\section{Use Aegerita Pers. 1794 (A) rather than Crocysporium Corda 1837 or Bulbillomyces Jülich 1974 (S)}

The monotypic genus Bulbillomyces, typified by B. farinosus, was described as the sexual morph of $A$. candida (Jülich 1974), the type of Aegerita, thus these generic names are synonyms. Lyman (1907) had earlier demonstrated the link between the sexual and asexual morphs using cultures and transferred Aegerita candida to Peniophora as P. candida (Pers.) Lyman 1907. Although two species were originally included in the protologue of Aegerita, Donk (1962) explains the history and selection of $A$. candida as type by Brongniart $(1824,1825)$, although Donk's interpretation of validation dates he used in 1962 must be adjusted by application of the current Shenzhen Code (Turland et al. 2018). Forty names have been described in Aegerita, although some of these have been found to belong outside of Aegerita in both Ascomycota and Basidiomycota (Kirk 2020). Within Aegerita only A. candida (as B. farinosus) has been sequenced. Recently Justo et al. (2017) showed that $A$. candida (as B. farinosus) was sister to the type of Hypochnicium, $H$. bombycinum. The name Aegerita candida is used about equally with $B$. farinosus (GSS A. candida $=131$, B. farinosus $=105$ ). 
Table 1 Recommended names of genera of Agaricomycotina among those that compete for use. The recommended accepted name is in bold; see text for the rationale for these decisions. For each name this list provides the author, its date and place of publication, type, its basionym, their dates of publication and the currently accepted name, if different. The action required is indicated in the last column, specifically approval by the Nomenclature Committee for Fungi (NCF) for those generic names that do not have priority and thus need protection

\section{Recommended generic name \\ Aegerita Pers. in Neues Mag. Bot. 1: 120. 1794, nom sanct., Fr., Syst. Mycol. 1: xli. 1821}

Typus: A. candida Pers. 1794, nom. sanct., Fr.

Aleurocystis Lloyd ex G. Cunn. in Trans. Roy. Soc. New Zealand 84: 234. 1956.

Typus: A. hakgallae (Berk. \& Broome) G. Cunn. 1956, basionym: Corticium hakgallae Berk. \& Broome 1875.

Armillaria (Fr) Staude, Schwämme Mitteldeutschl. 28: 130. 1857, basionym: Agaricus "trib." [unranked] Armillaria Fr. 1821, nom. sanct. Typus: A. mellea (Vahl) P. Kumm. 1871, basionym: Agaricus melleus Vahl 1790, nom. sanct., Fr.

Arthrosporella Singer in Fl. Neotrop. Monogr. 3: 17 1970.

Typus: A. ditopa (Singer) Singer 1970, basionym: Armillariella ditopa Singer 1951

Asterophora Ditmar in J. Bot. (Schrader) 3: 56. 1808 , nom. sanct., Fr., Syst. Mycol. 3: 205. 1829.

Typus: A. lycoperdoides (Bull.) Ditmar 1809, nom cons., basionym: Agaricus lycoperdoides Bull. 1784 nom. cons.

Athelia Pers., Traité Champ. Comest. 57. 1818. Typus: A. epiphylla Pers. 1818 (Thelephora epiphylla (Pers.) Fr., nom sanct., Fr.)

Bjerkandera P. Karst. in, Meddelanden af Societas pro Fauna et Flora Fennica 5: 38.1879.

Typus: Bjerkandera adusta (Willd.) P. Karst. 1879, basionym: Boletus adustus Willd. 1878, nom. sanct.

Botryobasidium Donk in Meded. Ned. Mycol. Ver. 18-20: 116. 1931

Typus: B. subcoronatum (Höhn. \& Litsch.) Donk 1931 basionym: Corticium subcoronatum Höhn. \& Litsch. 1907.

\begin{tabular}{ll} 
Synonymous alternate morph generic name(s) & Action required \\
\hline Crocysporium Corda, Icon. Fung. 1: 5. 1837. & None. \\
Typus: Crocysporium aegerita Corda 1837, now regarded & \\
as Aegerita candida Pers. 1794, nom. sanct., Fr. & \\
Bulbillomyces Jülich in Persoonia 8: 69. 1974. & \\
Typus: B. farinosus (Bres.) Jülich 1974, basionym Kneiffia & \\
farinosa Bres. 1903, now regarded as Aegerita candida
\end{tabular}

farinosa Bres. 1903, now regarded as Aegerita candida

Pers. 1794, nom. sanct., Fr.

Matula Massee in J. Roy. Microscop. Soc. London, ser. $2 \mathbf{8}$ 176. 1888.

Protection needed by NCF.

Typus: M. poroniiforme (Berk. \& Broome) Massee 1888, basionym: Artocreas poroniiforme Berk. \& Broome1875, now regarded as Aleurocystis hakgallae (Berk. \& Broome) G. Cunn. 1956

Rhizomorpha Roth in Ann. Bot. (Usteri) 1: 7. 1791, nom. sanct., Fr.

Typus: $R$. fragilis Roth 1791, now regarded as Armillaria mellea (Vahl) P. Kumm. 1871

Acurtis Fr., Summa Veg. Scand., Sectio Post. (Stockholm) 337. 1849, now regarded as Armillaria mellea (Vahl) P. Kumm. 1871.

Nothoclavulina Singer in Fl. Neotrop., Monogr. 3: 18. 1970.

Typus: N. ditopa Singer 1970, now regarded as

Arthrosporella ditopa (Singer) Singer 1970.

Ugola Adans., Fam. Pl. 2: 5. 1763.

Typus: Asterophora physaroides Fr. 1817, nom. sanct., Fr.. synonym: Ugola physaroides (Fr.) Redhead \& Seifert 2001, now regarded as Asterophora lycoperdoides (Bull.) Ditmar 1809.

Nyctalis Fr., Syst. Orb. Veg. 1: 78. 1825

Typus: N. parasitica (Bull.) Fr. 1838, basionym: Agaricus parasiticus Bull. 1791, nom. sanct., Fr., now Asterophora parasitica (Bull.) Singer 1951.

Fibularhizoctonia G.C. Adams \& Kropp in Mycologia 88: 464. 1996

Typus: F. carotae (Rader) G.C. Adams \& Kropp 1996, basionym Rhizoctonia carotae Rader 1948, now regarded as Athelia arachnoidea (Burt) Jülich 1972

Geotrichopsis Tzean \& Estey in Mycological Research 95 1351. 1991

Typus: G. mycoparasitica Tzean \& Estey 1991.

Acladium Link in Ges. Naturf. Freunde Berlin Mag. 3: 11. 1809

Typus: A. conspersum Link 1809, now regarded as Botryobasidium conspersum J. Erikss. 1958.

Alysidium Kunze in Kunze \& Schmidt, Mykol. Hefte 1: 11. 1817.

Typus: A. fulvum Kunze \& J.C. Schmidt 1817, nom. sanct. Fr., now regarded as Botryobasidium aureum Parmasto 1965

Haplotrichum Link in Willd., Sp. PI. 6(1): 52. 1824.

Typus: H. capitatum Link 1824, now regarded as Botryobasidium capitatum (Link) Rossman \& W.C. Allen 2016.

Sporocephalium Chevall., Fl. Gén. Env. Paris 1: 59. 1826.

Typus: S. capitatum (Link) Chevall. 1826, basionym: Haplotrichum capitatum Link. 1824, now regarded as Botryobasidium capitatum (Link) Rossman \& W.C. Allen 2016

Physospora Fr, FI Scan 360 1837

Typus: Sporotrichum rubiginosum Fr. 1832, now regarded as. Botryobasidium rubiginosum (Fr.) W.C. Allen \& Rossman 2016

Allescheriella Henn. in Hedwigia 36: 244. 1897.

Typus: A. uredinioides Henn. 1897, now regarded as
Protection needed by NCF.

None.

Protection needed by NCF. 
Table 1 (Continued)

\section{Recommended generic name}

Bullera Derx in Ann. Mycol. 28: 11. 1930

Typus: B. alba (W.F. Hanna) Derx 1930, basionym: Sporobolomyces albus W.F. Hanna 1929.

Chaetospermum Sacc., Syll. Fung. 10: 706. 1892. Typus: C. chaetosporum (Pat.) A.L. Sm. \& Ramsb. 1913, basionym: Tubercularia chaetospora Pat. 1888

Coprinellus P. Karst. in Bidrag Kännedom Finlands Natur Folk 32: 542. 1879

Typus: C. deliquescens (Bull.) P. Karst. 1879, basionym: Agaricus deliquescens Bull. 1786, nom. sanct., Fr.

Coprinopsis P. Karst. in Acta Soc. Fauna Fl. Fenn. 2: 27. 1881, nom. cons.

Typus: C. friesii (Quél.) P. Karst. 1881, basionym:

Coprinus friesii Quél. 1872

Cryptococcus Vuill. in Rev. Gén. Sci. Pures Appl. 12 741. 1901, nom. cons.

Typus: C. neoformans (San Felice) Vuill. 1901 basionym: Saccharomyces neoformans San Felice 1895, nom. cons.

Dacrymyces Nees, Syst. Pilze 89. 1816 [1816-17], nom. sanct., Fr., Syst. Mycol. 2: 228. 1822.

Typus: D. stillatus Nees 1816, nom. sanct., Fr.

Deconica (W.G. Sm.) P. Karst. in Bidrag Kännedom Finlands Natur Folk 32: 515. 1879, basionym: Agaricus subgen. Deconica W.G. Sm. 1870. Typus: D. bullacea (Bull.) Sacc. 1887, basionym Agaricus bullaceus Bull. 1793, nom. sanct., Fr.

Dendrocollybia R.H. Petersen \& Redhead in Mycol. Res. 105: 169. 2001.

Typus: D. racemosa (Pers.) R.H. Petersen \& Redhead 2001, basionym: Agaricus racemosus Pers. 1797, nom sanct., $\mathrm{Fr}$

Diacanthodes Singer in Lloydia 8: 141. 1945.

Typus: D. philippinensis (Pat.) Singer 1945, basionym: Daedalea philippinensis Pat. 1915, now regarded as Diacanthodes novoguineensis (Henn.) O. Fidalgo 1962

\section{Synonymous alternate morph generic name(s)}

Action required

Botryobasidium croceum Lentz 1967.

Neoacladium P.N. Singh \& S.K. Singh in Fungal Diversity

96: 189. 2019.

Typus: N. indicus P.N. Singh \& S.K. Singh 2019, now

regarded as Botryobasidium indicum (P.N. Singh \& S. K

Singh) R. Kirschner \& G. Langer 2021.

Bulleromyces Boekhout \& Á. Fonseca, in Antonie van Leeuwenhoek 59: 91. 1991.

Typus: B. albus Boekhout \& Á. Fonseca 1991, now regarded as Bullera alba (W.F. Hanna) Derx 1930.

Efibulobasidium K. Wells in Mycologia 67: 148. 1975.

Typus: E. albescens (Sacc. \& Malbr.) K. Wells 1975,

basionym: Epidochium albescens Sacc. \& Malbr. 1881, now regarded as Chaetospermum gossypinum (G.F. Atk.) Nag Raj 1993.

Ozonium Link in Ges. Naturf. Freunde Berlin Mag. 3: 21. 1809

Typus: O. auricomum Link 1809, now regarded as

Coprinellus domesticus (Bolton) Vilgalys et al. 2001.

Rhacophyllus Berk. \& Broome in J. Linn. Soc., Bot. 11: 559. 1871

Typus: R. lilacinus Berk. \& Broome 1871, now regarded as Coprinopsis lilacina (Berk. \& Broome) Redhead 2021. Zerovaemyces Gorovij, Dokl. Akad. Nauk Ukrainskoı SSR, Ser. B 39(8): 745. 1977.

Typus: Zerovaemyces copriniformis Gorovij, 1977, now regarded as Coprinopsis lilacina (Berk. \& Broome) Redhead 2021

Hormographiella Guarro \& Gené in Mycotaxon 45: 179.

1992.

Typus: H. aspergillata Guarro, Gené \& De Vroey 1992, now regarded as Coprinopsis cinerea (Schaeff.) Redhead, et al. 2001

Filobasidiella Kwon-Chung in Mycologia 67: 1198. 1976 "1975".

Typus: F. neoformans Kwon-Chung 1976, now regarded as Cryptococcus neoformans (San Felice) Vuill. 1901.

Ditiola Fr., Syst. Mycol. 2: 39. 1822, nom. sanct., Fr., non Ditiola P. Browne $1756=$ Schizophyllum Fr. 1815

Typus: D. radicata (Alb. \& Schwein.) Fr. 1822, nom. sanct, basionym: Helotium radicatum Alb. \& Schwein. 1805, now regarded as Dacrymyces radicatus (Alb. \& Schwein.) Donk 1931.

Dacryoscyphus R. Kirschner \& Zhu L. Yang in Antonie van Leeuwenhoek 87: 331. 2005.

Typus: D. chrysochilus R. Kirschner \& Zhu L. Yang 2005.

Pionnotes Fr. Summa Veg. Scand. 481. 1849.

Typus: P. capitata (Schwein.) Fr. 1849, basionym: Fusarium capitatum Schwein. 1832, now regarded as Dacrymyces chrysospermus Berk. \& M.A. Curtis 1873.

Pseudohelicomyces Garnica \& E. Valenz. in Mycol. Res. 104 739. 2000

Typus: P. albus Garnica \& E. Valenz. 2000, now regarded as Deconica merdaria (Fr.) Noordel. 2009.

Tilachlidiopsis Keissl. in Ann. Naturhist. Mus. Wien 37: 215. 1924.

Typus: T. racemosa Keissl. 1924, now regarded as Dendrocollybia racemosa (Pers.) R.H. Petersen \& Redhead 2001

Sclerostilbum Povah in Mycologia 24: 242. 1932.

Typus: S. septentrionale Povah 1932, now regarded as Dendrocollybia racemosa (Pers.) R.H. Petersen \& Redhead 2001.

Bornetina L. Mangin \& Viala in Compt. Rend. Hebd. Séances Acad. Sci. 136: 398, 1903.

Typus: B. corium L. Mangin \& Viala 1903, now regarded as Diacanthodes novoguineensis (Henn.) O. Fidalgo 1962.
None

None

Protection needed by NCF.

Protection needed by NCF.

None

None.

None.

Protection needed by NCF.

Protection needed by NCF. 
Table 1 (Continued)

Recommended generic name
Ditangium P. Karst., Fungi Fenniae Exsiccati 7: 656.

1867.

Typus: D. insigne P. Karst. 1870
Echinoporia Ryvarden in Ryvarden \& Johansen Prelim. Polyp. Fl. East Africa 325. 1980 Typus: E. hydnophora (Berk. \& Broome) Ryvarden 1980.

Femsjonia Fr., Summa Veg. Scand. 341. 1849 Typus: F. luteoalba Fr. 1849, now regarded as Femsjonia peziziformis (Lév.) P. Karst. 1876, basionym Exidia peziziformis Lév. 1848.

Fistulina Bull., Hist. Champ. France 313. 1791, nom. sanct., Fr., Syst. Mycol. 1: 396. 1821

Typus: F. buglossoides Bull. 1791, now regarded as

Fistulina hepatica (Schaeff.) With. 1801, nom. sanct.

Heteroacanthella Oberw. in Trans. Mycol. Soc. Japan 31: 208. 1990.

Typus: H. variabilis Oberw. \& Langer 1990.

Heterobasidion Bref. in Unters. Gesammtgeb. Mykol. 8: 154.1888

Typus: H. annosum (Fr.) Bref. 1888, basionym:

Polyporus annosus Fr. 1821, nom. sanct.

Hohenbuehelia Schulzer in Verh. K. K. Zool.-bot. Ges Wien 16: 45. 1866

Typus: H. petaloides (Bull.) Schulzer 1866, basionym: Agaricus petaloides Bull. 1785, nom. sanct., Fr.

Leucocoprinus Pat. in J. Bot. (Morot) 2: 16. 1888. Typus: L. cepistipes Pat. 1889

Marchandiomyces Diederich \& D. Hawksw. in Mycotaxon 37: 311. 1990.

Typus: M. corallinus (Roberge) Diederich \& D. Hawksw. 1990, basionym: Illosporium corallinum Roberge 1847.

Mycena (Pers.) Roussel, Fl. Calvados, ed. 264 ('46') 1806, basionym: Agaricus sect. Mycena Pers. 1797. Typus: M. galericulata (Scop.) Gray 1821, basionym: Agaricus galericulatus Scop. 1772, nom. sanct., Fr.

Myxarium Wallr., Fl. Crypt. Germ. 2: 260. 1833. Typus: M. nucleatum Wallr. 1833

Necator Massee, Bull. Misc. Inf., Kew 1898: 119. 1898. Typus: N. decretus Massee, 1898.

Neolentinus Redhead \& Ginns, Trans. Mycol. Soc. Japan 26(3): 357. 1985.

Typus: N. kauffmanii (A.H. Sm.) Redhead \& Ginns 1985, basionym: Lentinus kauffmanii A.H. Sm. 1946

Oliveonia Donk in Fungus 28: 20. 1958

Typus: O. fibrillosa (Burt) Donk 1958, basionym:

\section{Synonymous alternate morph generic name(s)}

Craterocolla Bref. in Unters. Gesammtgeb. Mykol. 7: 98

1888.

Typus: C. cerasi (Schumach.) Sacc. 1888, basionym Tremella cerasi Schumach. 1803, now regarded as Ditangium cerasi (Schumach.) Constantin \& J.L. Dufour 1891.

Poroidea Göttinger ex G. Winter, Rabenh. Krypt.-Fl., ed. 2 1, 2: 275.1885.

Typus: P. pithyophila Göttinger ex G. Winter 1885, now regarded as Ditangium cerasi (Schumach.) Constantin \& J.L. Dufour 1891.

Echinodia Pat. in Bull. Soc. Mycol. France 34: 199. 1918.

Typus: E. theobromae Pat. 1918, now regarded as Echinoporia hydnophora (Berk. \& Broome) Ryvarden 1980.

Cerinosterus RT. Moore in Stud. Mycol. 30:216. 1987. Typus: C. luteoalbus (de Hoog) R.T. Moore 1987, basionym: Sporothrix luteoalba de Hoog 1974, now regarded as a synonym of Femsjonia peziziformis (Lév.) P. Karst. 1876.

Confistulina Stalpers in Canad. J. Bot. 61: 1660. 1983. Typus: C. hepatica (Sacc.) Stalpers 1983, basionym: Ceriomyces hepaticus Sacc. 1888, now regarded as Fistulina hepatica (Schaeff.) With. 1801

Acanthellorhiza P. Roberts, Rhizoctonia-Forming Fungi 130. 1998.

Typus: A. globulifera P. Roberts 1999, now regarded as Heteroacanthella acanthophysa (Burds.) Oberw. 1990.

Spiniger Stalpers in Proc. Kon. Ned. Akad. Wetensch. C 77 402. 1974.

Typus: S. meineckellus (A.J. Olson) Stalpers 1974, basionym Cunninghamella meineckella A.J. Olson 1941, now regarded as Heterobasidion annosum (Fr.) Bref. 1888.

Nematoctonus Drechsler in Phytopathology 31: 779. 1941. Typus: N. tylosporus Drechsler 1941, now regarded as Hohenbuehelia tylospora (Drechsler) Thorn 2013.

Attamyces Kreisel in Z. Allg. Mikrobiol. Morphol. Physiol. Okol. Mikroorgan. 12: 648. 1972.

Typus: A. bromatificus Kreisel 1972, now regarded as Leucocoprinus gongylophorus (Möller) R. Heim 1957.

Marchandiopsis Ghobad-Nejhad \& Hallenb. in Taxon 59 1530. 2010.

Typus: M. quercina (J. Erikss. \& Ryvarden) Ghobad-Nejhad \& Hallenb., basionym Laeticorticium quercinum J. Erikss. \& Ryvarden 1976., now Marchandiomyces quercinus (J. Erikss. \& Ryvarden) Diederich \& D. Hawksw. 2015.

Decapitatus Redhead \& Seifert in Taxon 49: 795. 2000. Typus: D. flavidus (Cooke) Redhead \& Seifert 2000 basionym: Stilbum flavidum Cooke 1880, now Mycena citricolor (Berk. \& M.A. Curtis) Sacc. 1887.

Hyaloria Möller in Bot. Mitt. Tropen 8: 137. 1895.

Typus: H. pilacre Möller 1895, now regarded as Myxarium pilacre (Möller) R. Kirschner 2018.

Helicomyxa R. Kirschner \& Chee J. Chen in Stud. Mycol. 50 338. 2004

Typus: H. everhartioides R. Kirschner \& Chee J. Chen 2004, now regarded as Myxarium everhartioides (R. Kirschner \& Chee J. Chen) R. Kirschner 2018.

Upasia Harsojo-Tjokrosoedarmo \& Rifai. IImu Pertanian (Agric. Sci.) 5(1): 566. 1992.

Typus: U. salmonicolor (Berk. \& Broome) Harsojo-

Tjokrosoedarm, now regarded as Necator salmonicolor (Massee) K.H. Larss. et al. 2021.

Digitellus Paulet, Traité champ. (Paris) 2: 420, [485] and in Index. 1793.

Typus: Digitellus humanus Paulet 1793, now regarded as Neolentinus lepideus (Fr.) Redhead \& Ginns 1985.

Oliveorhiza P. Roberts in Folia Cryptog. Estonica 33: 128 1998.

\section{Action required}

None.

Protection needed by NCF.

None.

None

None

None.

None.

None.

None

None

None

None.

Protection needed by NCF 
Table 1 (Continued)

\section{Recommended generic name}

Sebacina fibrillosa Burt 1926

Pleurotus (Fr.) P. Kumm., Führ. Pilzk. (Zerbst) 104 1871, basionym: Agaricus "trib." [unranked] Pleurotus Fr. 1821, nom. sanct.

Typus: P. ostreatus (Jacq.) P. Kumm. 1871, basionym: Agaricus ostreatus Jacq. 1774, nom. sanct., Fr.

Polyporus P. micheli ex Adans., Fam. PI. 2: 10. 1763 nom. sanct. Fr., Syst. Mycol. 1: 341. 1821 Typus: P. tuberaster (Jacq. ex Pers.) Fr. 1815, nom sanct. Fr., basionym: Boletus tuberaster Jacq. ex Pers. 1801.

Postia Fr., Hymenomyc. Eur. 586. Oct 1874. Typus: Polyporus lacteus Fr. 1821, nom. sanct., now Postia lactea (Fr.) P. Karst. 1881

Rhizoctonia DC. in Lamarck \& de Candolle, Fl. Franç., ed. 3 5: 110. 1815.

Typus: R. solani J.G. Kühn 1858

Riopa D.A. Reid in Revue Mycol., Paris 33: 244. 1969. Typus: Riopa davidii D.A. Reid 1969, now regarded as Riopa metamorphosa (Fuckel) Miettinen \& Spirin 2016, basionym:

Polyporus metamorphosus Fuckel in Jahrb. Nassauischen Vereins Naturk. 27-28: 87. 1874

Scytinostroma Donk in Fungus 26: 19. 1956. Typus: S. portentosum (Berk. \& M.A. Curtis) Donk 1956, basionym: Corticium portentosum Berk. \& M.A. Curtis 1873.

Sistotrema Fr., Syst. Mycol. 1: 426. 1821, nom. sanct. Typus: S. confluens Pers. 1794, nom. sanct., Fr.

Sterigmatosporidium G. Kraep. \& U. Schulze in Antonie van Leeuwenhoek 48: 479. 1981 "1982". Typus: S. polymorphum G. Kraep. \& U. Schulze 1983.

Subulicystidium Parmasto, Consp. System. Corticiaceae (Tartu) 120. 1968.

Typus: S. longisporum (Pat.) Parmasto 1968, basionym: Hypochnus longisporus Pat. 1894

Tomophagus Murrill in Torreya 5: 197. 1901 Typus: T. colossus (Fr.) Murrill 1901, basionym Polyporus colossus Fr. 1851

Trechispora P. Karst. in Hedwigia 29: 147. 1890 Typus: T. onusta P. Karst. 1890, now regarded as Trechispora hymenocystis (Berk. \& Broome) K.H. Larss. 1994.

Trimorphomyces Bandoni \& Oberw. in Syst. Appl. Microbiol. 4: 106. 1983.

Typus: T. papilionaceus Bandoni \& Oberw. 1983.

Synonymous alternate morph generic name(s)

Action required

Typus: O. anapauxilla P. Roberts 1998, now regarded as

Oliveonia pauxilla (H.S. Jacks.) Donk 1958.

Antromycopsis Pat. \& Trab. in Bull. Soc. Mycol. France $\mathbf{1 3}$

215. 1897.

Typus: A. broussonetiae Pat. \& Trab., 1897, now regarded as Pleurotus cystidiosus O.K. Mill. 1969

Mycelithe Gasp. in Atti Accad. Pontan. 2: 221. 1842.

Typus: M. fungifera Gasp. 1842, now regarded as Polyporus tuberaster (Jacq. ex Pers.) Fr. 1815

Ptychogaster Corda, Icon. Fung. 2: 23. 1838 Typus: P. albus Corda 1838, now regarded as Postia ptychogaster (F. Ludw.) Vesterh. 1996.

Thanatephorus Donk in Reinwardtia 3: 376. 1956. Typus: T. cucumeris (A.B. Frank) Donk 1956, basionym: Hypochnus cucumeris A.B. Frank 1883, now regarded as Rhizoctonia solani J.G. Kühn 1858.

Sporotrichum Link in Ges. Naturf. Freunde Berlin Mag. 3: 13. 1809.

Typus: S. aureum Link 1809 nom. illeg. non (Pers.) Fr. 1832

[ $=$ Trichoderma aureum Pers. $1796=$ Botryobasidium

aureum Parmasto 1965], now regarded as Riopa

metamorphosa (Fuckel) Miettinen \& Spirin 2016.

Michenera Berk. \& M.A. Curtis in J. Linn. Soc., Bot. 10: 333. 1868. "1869".

Typus: M. artocreas Berk. \& M.A. Curtis 1868, now regarded as Scytinostroma artocreas (Berk. \& M.A. Curtis) K.-H. Larss. 2018.

Artocreas Berk. \& Broome, J. Linn. Soc., Bot. 14(74):

73. 1873 "1875".

Typus: Artocreas micheneri Berk. \& M.A. Curtis. 1875, now regarded as as Scytinostroma artocreas (Berk. \& M.A. Curtis) K.-H. Larss. 2018

Stereofomes Rick in Egatea 13: 435. 1928.

Typus: S. nodulosum Rick 1928, now regarded as

Scytinostroma nodulosum (Rick) K-H Larss. 2018.

Licrostroma P.A. Lemke in Canad. J. Bot. 42: 762. 1964.

Typus: L. subgiganteum (Berk.) P.A. Lemke 1964, basionym:

Corticium subgiganteum Berk. 1873, now regarded as

Scytinostroma artocreas (Berk. \& M.A. Curtis) K.-H. Larss 2018.

Ingoldiella D.E. Shaw in Trans. Brit. Mycol. Soc. 59: 258 1971

Type: I. hamata D.E. Shaw 1971, now regarded as Sistotrema hamatum Nawawi \& J. Webster 1982.

Cuniculitrema J.P. Samp. \& R. Kirschner in Antonie van Leeuwenhoek 80: 155. 2001.

Typus: C. polymorpha R. Kirschner \& J.P. Samp. 2001.

Aegeritina Jülich in Int. J. Mycol. Lichenol. 1: 282. 1984. Typus: A. tortuosa (Bourdot \& Galzin) Jülich 1984, basionym: Aegerita tortuosa Bourdot \& Galzin 1928, now regarded as Subulicystidium longisporum (Pat.) Parmasto 1968

Thermophymatospora Udagawa et al. in Mycotaxon 27 : 100. 1986.

Typus: T. fibuligera Udagawa, et al. 1986, now regarded as Tomophagus colossus (Fr.) Murrill 1905.

Osteomorpha G. Arnaud ex Watling \& W.B. Kendr. in Naturalist (Hull) ser. 3 104: 1. 1978.

Typus: O. fragilis G. Arnaud ex Watling \& W.B. Kendr. 1979, now regarded as Trechispora stevensonii (Berk. \& Broome) K.H. Larss. 1995.

Anastomyces W.P. Wu et al. in Mycol. Res. 101: 1318. 1997. Typus: A. microsporus W.P. Wu, et al. 1997, now regarded as Trimorphomyces papilionaceus Bandoni \& Oberw. 1983.
None.

None.

Protection needed by NCF.

None.

Protection needed by NCF.

Protection needed by NCF

None.

None.

None

None.

None.

None 
Table 1 (Continued)

Recommended generic name
Tulasnella J. Schröt. in Cohn, Krypt.-Fl. Schlesien 3(1):
397. June 1888.
Typus: T. lilacina J. Schröt. 1888, now regarded as
Tulasnella violea (Quél.) Bourd. \& Galz. 1909,
basionym Hypochnus violeus Quél. 1883.

Typhula (Pers.) Fr., Observ. Mycol. 2: 296. 1818, basionym: Clavaria y Typhula Pers. 1801. Typus: T. phacorrhiza (Reichard) Fr. 1818, nom. sanct. Fr., basionym: Clavaria phacorrhiza Reichard 1780.

Waitea Warcup \& P.H.B. Talbot in Trans. Br. Mycol. Soc. 45: 503. 1962.

Typus: W. circinata Warcup \& P.H.B. Talbot 1962.

Wolfiporia Ryvarden \& Gilb. in Mycotaxon 19: 141 1984.

Typus: W. cocos (F.A. Wolf) Ryvarden \& Gilb. 1984, basionym: Poria cocos F.A. Wolf 1922, nom. cons.

$\begin{array}{ll}\text { Synonymous alternate morph generic name(s) } & \text { Action required } \\ \text { Hormomyces Bonord., Handb. Mykol. 150. 1851. } & \text { Protection needed by NCF. } \\ \text { Typus: H. aurantiacus Bonord. 1851, now regarded as } & \\ \text { Tulasnella aurantiaca (Bonord.) J. Mack \& Seifert 2021. } & \\ \text { Prototremella Pat. in J. Bot. (Morot) 2: 269. 1888. } & \\ \text { Typus: P. tulasnei Pat. August 1888, now regarded as } & \\ \text { Tulasnella tulasnei (Pat.) Juel 1897. } \\ \text { Hormisciopsis Sumst. in Mycologia 6: 32. 1914. } \\ \text { Typus: H. gelatinosa Sumst. 1914, now regarded as } \\ \text { Tulasnella aurantiaca (Bonord.) J. Mack \& Seifert 2021. } \\ \text { Epulorhiza R.T. Moore in Mycotaxon 29: } 94.1987 . \\ \text { Typus: E. repens (G.E. Bernard) R.T. Moore 1987, basionym: } \\ \text { Rhizoctonia repens G.E. Bernard 1909, now regarded as } \\ \text { Tulasnella deliquescens (Juel) Juel 1914. }\end{array}$

Tulasnella deliquescens (Juel) Juel 1914

Sclerotium Tode, Fung. Mecklenb. Sel. 1: 2. 1790, nom. sanct., Fr.

Typus: S. complanatum Tode 1790, now regarded as Typhula phacorrhiza (Reichard) Fr. 1818.

Chrysorhiza T.F. Andersen \& Stalpers in Sneh et al., Rhizoctonia Species, Taxonomy, Molecular Biology, Ecology, Pathology and Disease Control (Dordrecht): 58. 1996.

Typus: Rhizoctonia zeae Voorhees 1934, now regarded as Waitea zeae (Voorhees) J.A. Crouch \& Cubeta 2021.

Gemmularia Raf. in J. Phys. Chim. Hist. Nat. Arts 89: 106. 1819, nom. sanct., Fr., 1823.

Typus: G. rugosa Raf. 1819, now regarded as Wolfiporia cocos (F.A. Wolf) Ryvarden \& Gilb. 1984.

Pachyma Fr., Syst. Mycol. 2: 242. 1822, nom. sanct.

Typus: P. cocos Fr. 1822, basionym: Sclerotium cocos

Schwein. 1822, now regarded as Wolfiporia cocos (F.A.

Wolf) Ryvarden \& Gilb. 1984.

Tucahus Raf., Medical flora, or, Manual of the medical

botany of the United States of North America. 2:

270. 1830.

Typus: T. rugosus (Raf.) Raf., now regarded as Wolfiporia

$\operatorname{cocos}$ (F.A. Wolf) Ryvarden \& Gilb. 1984.
Protection needed by NCF.

None.

Protection needed by NCF.
Aegerita candida is the name used by ecologists who have examined the extracellular enzymatic activity of this aeroaquatic fungus (Abdullah and Taj-Aldeen 1989). An obscure generic name, Crocysporium (GSS 32), is typified by $C$. aegerita, a name that is considered a synonym of Aegerita candida (Donk 1962), thus Crocysporium is a later synonym of Aegerita. Five other species names have been described in Crocysporium of which all but two are placed elsewhere and none have been widely used. Given its priority, the greater number of names, and use in ecological literature, we recommend the use of Aegerita.

\section{Protect Aleurocystis Lloyd ex G. Cunn. 1956 (S) over Matula Massee 1888 (A)}

The sexual morph of the type of Aleurocystis, A. hakgallae (as Peniophora hakgallae), was connected to the asexual morph Matula poroniiforme, type of Matula, by Petch (1926) and later accepted by Martin (1940) and Giraldo et al. (2017), thus the generic names Aleurocystis and Matula are synonyms. When he validated the name Aleurocystis, Cunningham (1956) included the generic name Matula as a synonym, and also listed Artocreas poroniiforme [as poroniaeforme] as a synonym of the type, Aleurocystis hakgallae. Cunningham (1956) also corrected the orthography from "Aleurocystus" that had been attributed to "McGinty" by Lloyd (1921). Under Art. F.8.1 both generic names Aleurocytis and Matula are legitimate. The basionyms for these species, namely Corticium hakgallae and Artocreas poroniiforme, were published in the same article (Berkeley and Broome 1875) and thus had equal priority. Cunningham (1956) placed Artocreas poroniiforme in synonymy of Aleurocystis hakgallae, thereby establishing priority for the species epithet, hakgallae. The only additional species in Matula, $M$. rombellii, is considered a synonym of $M$. poroniiforme, thus is A. hakgallae (Martin 1942). The only additional species of Artocreas is its lectotype, A. micheneri, now considered a synonym of Scytinostroma artocreas [see below under Scytinostroma]. The genus Aleurocystis has been widely used, includes four names (Ryvarden 1998; Hjorstam and Ryvarden 2000; Rajchenberg and Robledo 2005), and requires no name changes, thus Aleurocystis is recommended for protection.

One final note is that Massee (1888) published a new ordinal name, Matulales (as Matuleae), typified by Matula, skipping over description of a family. Fortunately, priority of names only extends to the level of family (Art. 11.1). 
Table 2 Species names proposed for protection with the names proposed for rejection. See text for the rationale about the proposed protected names. For each name this list provides the currently accepted name, if different, the name to be protected and rejected, author, place and date of publication, and type. The names proposed for protection will be evaluated and recommended for approval by the Nomenclature Committee for Fungi

Names proposed for protection
Botryobasidium conspersum J. Erikss. in Symb. Bot. Upsal. 16: 133. 1958.
Typus: Sweden: Gästrikland: Gäyle, Lövudden, on decayed wood of Betula, 25 Jun
1951, J A Nannfeldt 11434a (UPS)

1951, J A Nannfeldt 11434a (UPS)

Botryobasidium croceum Lentz in Mycopathol. Mycol. Appl. 32: 6.1966 [1967]. Typus: USA: Mississippi. Greenville, near Huntington Point, on dead stump, 1960, P.L. Lentz 60-394 (BPI 1107361 - holotype).

Laccocephalum mylittae (Cooke \& Massee) Núñez \& Ryvarden. Syn. Fung. (Oslo) 10: 31.1995 (Polyporus mylittae Cooke \& Massee in Cooke, Grevillea 21: 37. 1892) Typus: [Australia, Victoria, Beechworth, J.W. Howard], "Growing on Mylitta australis. S. Australia [sic]" (K(M))

Phanerochaete chrysosporium Burds. in Mycotaxon 1: 124.1974. Typus: U.S.A.: Arizona, Cochise Co., Peloncillo Mts., Guadelupe Canyon, on dead wood of Platanus wrightii (Arizona sycamore), 25 Aug. 1971, Burdsall 6251 (Holotype: CFMR; Isotype: Same data ARIZ - AN 003206)

Postia ptychogaster (F. Ludw.) Vesterh. in Knudsen \& Hansen, Nordic J. Bot. 16: 213. 1996 (Polyporus ptychogaster F. Ludw. in Z. Gesammten Naturwiss (Halle) 3: 424. 1880) Typus: Taf. XIII in Z. Gesammten Naturwiss (Halle) 1880. Lectotypus designated here: MBT 395397.

Riopa metamorphosa (Fuckel) Miettinen \& Spirin in MycoKeys 17: 27.2016 (Polyporus metamorphosus Fuckel in Jahrb. Nassauischen Vereins Naturk. 27-28: 87. 1874). Typus: Germany: Oestrich (Nassau): Mittelheimer Vorderwald, rotten trunk of Quercus, "Herbier Fuckel 1894, Herbier Barbey-Boissier", no. 2008 (S F43290 - lectotype designated by Miettinen et al. 2016). Czech Republic. Moravia: Lanžhot, Ranšpurk virgin forest, rotten trunk of Quercus robur, 5 Oct 1988, Z. Pouzar (PRM 871894 - epitype designated by Miettinen et al. 2016; H 7008579 - isoepitype).

Protect Armillaria (Fr.) Staude 1857 (S) over Rhizomorpha Roth 1791 (A) and Acurtis Fr. 1849 (A/S)

Armillaria is a well-known genus of mushroomforming fungi lectotypified by A. mellea (Clements and Shear 1931), the honey fungus, which is now recognized in a restricted sense within a complex amalgam of segregate species (Pegler 2000). The lectotype of Rhizomorpha, R. fragilis, represents rhizomorphs of $A$. mellea (Donk 1962), thus Armillaria and Rhizomorpha are synonyms. Donk (1962) provides a lengthy discussion of the lectotypification of Rhizomorpha. Rhizomorpha was accepted at the rank of genus in Fries (1821) and therefore is sanctioned, whereas Agaricus [unranked "tribus"] Armillaria is sanctioned only as an infrageneric name. Therefore, at the generic rank, Armillaria requires protection over Rhizomorpha. Although 117 names exist in Rhizomorpha, this generic name has been applied to the sterile rhizomorphs
Rejected names

Acladium conspersum Link in Ges. Naturf. Freunde Berlin Mag. 3: 11. 1809, nom. sanct, Fr., Syst. Mycol. 3: 419. 1832

Sporotrichum oosporum Ehrenb., Sylv. Mycol. Berol. 22. 1818.

Sporotrichum helvolum Wallr., Fl. Crypt. Germ. 2: 280. 1833.

Sporotrichum floccosum Bres. in Hedwigia 35: 301. 1896.

Rhinotrichum olivaceum Bres., Fung. Trident. 2: 106. 1900.

Rhinotrichum bicolor Sumst. in Mycologia 3: 50. 1911.

Rhinotrichum noblesiae Sumst. in Mycologia 29: 250. 1937.

Mucor croceus Mont. in Sagra, Ann. Sci. Nat., Bot. Sér. 2 17: 121. 1842.

Gymnosporium fulvum Berk. \& M.A. Curtis in Berkeley, J. Linn. Soc., Bot. 10: 355. 1868 "1869".

Allescheriella uredinioides Henn. in Hedwigia 36: 244. 1897.

Mylitta australis Berk. in Ann. Mag. Nat. Hist. 3: 326. 1839.

Typus: [Australia, Tasmania], "Van Diemen's Land, collection of Sir. W.J. Hooker"

Sporotrichum pruinosum Gilman \& E.V. Abbott in lowa State Coll. J. Sci. 1: 306. 1927.

Trichoderma fuliginoides Pers., Syn. Meth. Fung. 1: 231. 1801. Ptychogaster albus Corda, Icon. Fung. 2: 24. 1838.

Mucor aurantius Bull., Hist. Champ. France 1: 103. 1791.

Sporotrichum aurantiacum Fr., Syst. Mycol. 3: 423. 1832, nom. sanct. produced by different kinds of fungi not related to the type. For example, Rhizomorpha hippotrichoides is Xylaria hippotrichoides and $R$. necatrix is Rosellinia necatrix, both in Ascomycota (Kirk 2020). The generic name Acurtis was based upon Clavaria gigantea, which itself was based upon structures now recognized as the so called carpophoroids of Entoloma abortivum. For many years these carpophoroids were considered to be aborted, parasitized basidiomes of the Entoloma (Donk 1962; Watling 1974), but it has been shown that they are aborted basidiomes of Armillaria (Lindner Czederpiltz et al. 2001; Fukuda et al. 2003). Instead of threatening the name Entoloma, this oft debated generic name threatens the name Armillaria. Because Armillaria is a clearly circumscribed and a well-known genus with species causing diseases of economic importance (Fox 2000), we recommend protection of the generic name Armillaria. 
Table 3 Family names proposed for protection with the names proposed for rejection. See text for the rationale about the proposed protected names. This list provides the names to be protected or rejected, author, their place and date of publication, and type. The names proposed for protection will be evaluated and recommended for approval by the Nomenclature Committee for Fungi

\begin{tabular}{ll}
\hline Names proposed for protection & Rejected names \\
\hline Psathyrellaceae Vilgalys, Moncalvo \& Redhead in Taxon & Zerovaemycetaceae Gorovij in Dopov. Akad. Nauk URSR, \\
$\begin{array}{l}\text { 50: 226. 2001. } \\
\text { Typus: Psathyrella (Fr.) Quél. }\end{array}$ & Ser. B 39(8): 745. 1977. \\
Typhulaceae Jülich in Biblioth. Mycol. 85: 393. 1982 [1981]. & Typus: Zerovaemyces Gorovij \\
Typus: Typhula (Pers.) Fr. & Sclerotiaceae Dumort. [as 'Sclerotaceae'], Comment. Bot. \\
& (Tournay) 69. 1822. \\
\hline
\end{tabular}

\section{Use Arthrosporella Singer 1970 (S) rather than Nothoclavulina Singer 1970 (A)}

The monotypic generic names Arthrosporella and Nothoclavulina were published for the sexual and asexual morphs of the same species in the same publication (Singer 1970), specifically $A$. ditopa and $N$. ditopa, thus they are synonyms having equal priority. Here we designate $A$. ditopa as having priority. This species was re-described and discussed by Stalpers et al. (1991) and Baroni et al. (2007). Because Arthrosporella is more widely cited (GSS Arthrosporella $=24$, Nothoclavulina $=11$ ) and is typified by the mushroom-like sexual morph, we here designate Arthrosporella as having priority and recommend Arthrosporella for use.

\section{Protect Asterophora Ditmar 1809 (S) over Ugola Adans.} 1763 (A) and use rather than Nyctalis Fr. 1825 (S)

The generic name Asterophora includes species that are parasitic on other mushrooms especially Lactarius and Russula (Russulaceae). Asexual morphs of species of Asterophora have been described in Ugola typified by $U$. physaroides, a synonym of Asterophora physaroides. Redhead and Seifert (2001a) unraveled and clarified the nomenclature of these generic names including Nyctalis as a synonym of Asterophora. They also proposed conservation of the name of the type of Asterophora as A. lycoperdoides over the earlier name $A$. agaricoides (Redhead and Seifert 2001b) and this was approved by the NCF (Gams 2004). Redhead and Seifert (2001a) recognized three species in Ugola, all of which have names in Asterophora. Redhead and Seifert (2001b) also recognized $A$. lycoperdoides and $A$. physaroides as the same species, thus Asterophora and Ugola are synonyms. Although Ugola has priority, this generic name is rarely used while Asterophora includes approximately 20 names and is widely used. For these reasons we recommend that Asterophora be protected over Ugola and be used instead of Nyctalis.

\section{Use Athelia Pers. 1818 (S) rather than Fibularhizoctonia G.C. Adams \& Kropp 1996 (A)}

The generic name Athelia, lectotypified by $A$. epiphylla by Donk (1949), includes about 40 species names and is widely used for saprobic, crustose, wood-inhabiting fungi as well as important plant pathogens (Jülich 1972). Fibularhizoctonia, typified by F. carotae, was described for the sclerotial-forming Rhizoctonia carotae (Rader 1948) and is recognized as the asexual morph of Athelia arachnoidea, a species that causes a cold-storage disease of carrots throughout temperate regions of the world (Adams and Kropp 1996). The two additional species of Fibularhizoctonia, sometimes misspelled 'Fibulorhizoctonia', are recognized in Athelia (De Vries et al. 2008; Kirk 2014). One species of Athelia, A. rolfsii (Curzi) C.C. $\mathrm{Tu} \&$ Kimbr. 1978 (syn. Sclerotium rolfsii Sacc. 1911) is the scientific name for a soilborne pathogen that causes blight stem and root rot diseases of crop and nursery plants throughout the world (Punja 1985). Athelia is used much more commonly than Fibularhizoctonia (GSS Athelia $=5280$, Fibularhizoctonia $=54)$. Given its priority, greater number of species, and widespread use, the generic name Athelia is recommended for use.

\section{Use Bjerkandera P. Karst. 1879 (S) over Geotrichopsis Tzean \& Estey 1991 (A)}

Geotrichopsis was introduced for G. mycoparasitica, a hyphomycete that produced thallic-arthric conidia and was isolated as a mycoparasite in a culture of an Arthrobotrys species. Because it had dolipore septa, it was considered to be the asexual state of a basidiomycete (Tzean and Estey 1991). It was described as new because it did not match the features in culture of various basidiomycetes known to produce asexual morphs, including Polyporus adustus (now Bjerkandera adusta). However, sequences of the ITS (MH862453) and LSU (MH874100) regions have been obtained from CBS 687.93, the ex-type culture of G. mycoparasitica (Vu et al. 2019), and the sequences have high BLAST 
matches to sequences identified in GenBank as B. adusta (ITS, 100\% to several sequences including MF161298; LSU, 99.89\% to KT305936). In a phylogenetic analysis of the combined ITS and LSU regions of a range of fungi isolated from Prunus, G. mycoparasitica CBS 687.93 fell within a well-supported clade otherwise comprised of $B$. adusta and B. fumosa, in a subclade with two sequences, one labelled B. adusta and the other B. cf. adusta (Bien and Damm 2020). Compared to sequences in the phylogeny of six species of Bjerkandera in Motato-Vásquez et al. (2020), which includes multiple sequences of each of $B$. adusta and B. fumosa, the ITS sequence from the ex-type culture of $G$. mycoparasitica has BLAST matches of $98.53-99.25 \%$ to sequences of B. adusta, 98.19-98.54\% to sequences of B. albocinerea (the sister taxon to B. adusta), and $94.02-94.97 \%$ to sequences of B. fumosa. The sequence of B. albocinerea MH625420, which has the highest similarity, slightly overlapping with the range of similarity with $B$. adusta, is shorter, and lacks several characteristic bases that distinguish $B$. albocinerea from B. adusta. Consequently, Geotrichopsis should be considered a synonym of Bjerkandera and $G$. mycoparasitica placed in synonymy under B. adusta. Because Geotrichopsis has only been used for one species and is hardly mentioned in the literature (GSS Bjerkandera $=10,700$, Geotrichopsis $=26$ ), we recommend use of Bjerkandera.

Protect Botryobasidium Donk 1931 (S) over Acladium Link 1809 (A), Alysidium Kunze 1817 (A), Haplotrichum Link 1824 (A), Sporocephalium Chevall. 1826 (A), Physospora Fr. 1835 (A), Allescheriella Henn. 1897 (A) and Neoacladium P.N. Singh \& S.K. Singh 2019 (A)

The generic name Botryobasidium is typified by B. subcoronatum, while the holotype of Haplotrichum is H. capitatum. Holubová-Jechová (1976) recognized the generic name Haplotrichum for the asexual morphs of Botryobasidium "as a result of the conservation of the generic name Oidium for conidial states of Erysiphe ..." (Partridge et al. 2001a) and this was accepted in a monographic account of Botryobasidium (Langer 1994). Botryobasidium includes species with or without Haplotrichum asexual morphs, clamp connections, smooth or ornamented basidiospores, and chlamydospores or cystidia, but excludes morphologically similar species that produce secondary spores or outgrowing clamps (Langer 1994). Partridge et al. (2001a, b, 2002) provided a comprehensive study of Haplotrichum in which $H$. capitatum is recognized as the asexual morph of $B$. candicans. Haplotrichum capitatum is based on Acladium capitatum, therefore, Rossman et al. (2016b) recombined this name as Botryobasidium capitatum. Botryobasidium candicans is now considered a synonym of B. capitatum. They also placed Sporotrichum rubiginosum in Botryobasidium as B. rubiginosum. The type of Physospora, P. rubiginosa, is also based on Sporotrichum rubiginosum, thus Physospora is a synonym of Botryobasidium. Donk (1962) reviewed the typification of Physospora concluding that Sumstine (1911) was the first to lectotypify this genus. The generic name Physospora was considered dubious by Donk (1962) and has been little used. Acladium, lectotypified by $A$. conspersum, now regarded as $B$. conspersum, is also congeneric with Botryobasidium and Haplotrichum as outlined by HolubováJechová (1976). Four species were originally included in Acladium. Both Clements and Shear (1931) and Hughes (1958) regarded $A$. conspersum as the type according to Donk (1962). The generic name Alysidium typified by $A$. fulvum has been considered a synonym of Haplotrichum (Holubová-Jechová 1980) as explained by Partridge et al. (2001a) who regarded A. fulvum as a synonym of the asexual morph of B. aureum. Sporocephalium was lectotypified with $S$. capitatum by Hughes (1958) who considered Sporocephalium a synonym of Acladium. Partridge et al. (2002) regarded Acladium to be a synonym of Haplotrichum with Sporocephalium capitatum as the asexual morph of B. candicans, now regarded as B. capitatum. Only four species of Sporocephalium, typified by $S$. capitatum, now B. capitatum, have been described, and this generic name is relatively obscure. Another generic name, Allescheriella is typified by $A$. uredinoides, now regarded as a synonym of $B$. croceum by Partridge et al. (2002), although Hughes (1951) recognized it as B. fulvum. Either way Allescheriella is a synonym of Botryobasidium. A recently described monotypic asexual morph generic name, Neoacladium, is here considered to be a synonym of Botryobasidium rather than sister to that genus (Hyde et al. 2019).

Despite the lack of a known asexual morph of $B$. subcoronatum, type of Botryobasidium, this species is considered to be congeneric with Botryobasidium conspersum, as shown by Binder and Hibbett (2002) and Larsson (2007), in which $H$. conspersum, H. curtisii, and $B$. isabellinum constitute a monophyletic group. Based on a nuclear ribosomal DNA large subunit (nLSU) analysis, Moncalvo et al. (2006) demonstrated that Botryobasidium included species with asexual morphs and smooth basidiospores (e. g. $B$. candicans, B. conspersum, B. simile,), species without asexual morphs and smooth basidiospores (e. g. $B$. obtusisporum and B. vagum), and species without an asexual morph and ornamented basidiospores (e. g. B. isabellinum) as well as the type B. subcoronatum. These species formed a well-supported monophyletic group as previously demonstrated by micromorphological and ultrastructural characters (Langer 1994; Langer and Langer 1998). Thus, Botryobasidium, Acladium, and Haplotrichum, as well as the lesser known Alysidium, Sporocephalium, Physospora, Allescheriella, and Neoacladium, are all synonyms. 
Although Acladium, Haplotrichum, Physospora and Allescheriella have priority, these names are less frequently cited than Botryobasidium (GSS Botryobasidium $=1010, \quad$ Acladium $=884, \quad$ Alysidium $=196$, Haplotrichum $=206$, Sporocephalium $=4$, Physospora $=$ 28, Allescheriella =167). In addition, Botryobasidium includes a greater number of names, thus we recommend Botryobasidium for protection.

Five names in Botryobasidium are proposed for protection because they are widely used or already placed in Botrybasidium. In addition, 17 names described in Haplotrichum or other synonymous genera known to belong in Botryobasidium are re-combined in that genus here.

\section{Names proposed for protection:}

Botryobasidium aureum Parmasto, Eesti N. S. V. Tead. Akad. Toimet., Biol. 14: 220. 1965.

Synonyms: Monilia aurea J.F. Gmel., Syst. Nat., Edn 13 2(2): 1487. 1792.

Trichoderma dubium Pers., Syn. meth. fung. 1: 233. 1801, nom. sanct. Fr., Syst. Mycol. 3: 216. 1829.

Many additional earlier synonyms are listed in Kirk (2020).

Botryobasidium conspersum J. Erikss., Symb. Bot. Upsal. 16: 133. 1958.

Type: See Table 2.

Synonyms to be protected over: Acladium conspersum Link, Ges. Naturf. Freunde Berlin Mag. 3: 11. 1809.

Sporotrichum oosporum Ehrenb., Sylv. mycol. berol. 22. 1818.

Sporotrichum helvolum Wallr., Fl. crypt. Germ. 2: 280. 1833.

Sporotrichum floccosum Bres., Hedwigia 35: 301. 1896.

Rhinotrichum olivaceum Bres., Fung. trident. 2(14): 106. 1900.

Rhinotrichum bicolor Sumst., Mycologia 3: 50. 1911.

Rhinotrichum noblesiae Sumst., Mycologia 29: 250. 1937.

Botryobasidium croceum Lentz, Mycopathol. Mycol. Appl. 32: 6. 1967 “1966”.

Type: See Table 2.

Synonyms to be protected over: Mucor croceus Mont., Ann. Sci. Nat., Bot., sér. 2 17: 121. 1842.

Gymnosporium fulvum Berk. \& M.A. Curtis, J. Linn. Soc., Bot. 10: 355. 1868 “1869”.

Rhinotrichum fulvum (Berk. \& M.A. Curtis) Berk. \& M.A. Curtis, Grevillea 2(19): 108. 1874.

Allescheriella uredinioides Henn., Hedwigia 36: 244. 1897.

Pellicularia lembospora D.P. Rogers, Farlowia 1: 109. 1943 “1943-1944”.
Synonyms: Botryobasidium lembosporum (D.P. Rogers) Donk, Fungus 28: 26. 1958.

Hymenochaete tomentosa Berk. \& M.A. Curtis, J. Linn. Soc., Bot. 10: 335. 1868 “1869”.

Botryobasidium simile Hol.-Jech., Česká Mykol. 23: 99. 1969.

Synonyms: Oidium simile Berk., J. Bot. (Hooker) 4: 310. 1845.

Monilia aureofulva Cooke \& Ellis, Grevillea 8(no. 45): 12. 1879 .

Oidium biforme Linder, Lloydia 5: 188. 1942.

The names listed above for the sexual morph have older names that could be applied to the asexual morph. Because use of the oldest epithet would require a new combination that would displace a familiar and commonly used name, the five names in Botryobasidium listed above are proposed for protection. This synonymy is based primarily on Partridge et al. (2001a, b, 2002).

New combinations:

Botryobasidium armeniacum (Berk. \& M.A. Curtis) G. Langer, comb. nov.

MycoBank MB 837648

Basionym: Rhinotrichum armeniacum Berk. \& M.A. Curtis, Grevillea 3(27): 108. 1875.

Botryobasidium caribense (Hol.-Jech.) G. Langer, comb. nov.

MycoBank MB 837649

Basionym: Oidium caribense Hol.-Jech., Ceská Mykol. 23: 218. 1969.

Botryobasidium elongatum (Linder) G. Langer, comb. nov. MycoBank MB 837651

Basionym: Oidium elongatum Linder, Lloydia 5: 191. 1942.

Botryobasidium gracile (Hol.-Jech.) G. Langer, comb. nov.

MycoBank MB 837660

Basionym: Haplotrichum gracile Hol.-Jech., Ceská Mykol. 30: 4. 1976.

Botryobasidium indicum (P.H. Singh \& S.K. Singh) R. Kirschner \& G. Langer, comb. nov.

MycoBank MB 837873

Basionym: Neoacladium indicum P.N. Singh \& S.K. Singh, Fungal Diversity 96: 189. 2019.

Botryobasidium laevisporum (Cooke) G. Langer, comb. nov.

MycoBank MB 837652 
Basionym: Zygodesmus laevisporus Cooke, Grevillea 6(40): 139. 1878.

\author{
Botryobasidium magnisporum (Linder) G. Langer, \\ comb. nov. \\ MycoBank MB 837653 \\ Basionym: Oidium magnisporum Linder, Lloydia 5: \\ 179. 1942.
}

Botryobasidium morganii (Linder) G. Langer, comb. nov. MycoBank MB 837654

Basionym: Oidium morganii Linder, Lloydia 5: 197. 1942.

Botryobasidium ovalisporum (Linder) G. Langer, comb. nov.

MycoBank MB 837865

Basionym: Oidium curtisii var. ovalisporum Linder, Lloydia 5: 204. 1942.

Botryobasidium parmastoi (G. Langer) G. Langer, comb. nov.

MycoBank MB 837655

Basionym: Haplotrichum parmastoi G. Langer, Folia Cryptog. Estonica 33: 63. 1998.

Botryobasidium perseae (R.F. Castañeda) G. Langer, comb. nov.

MycoBan MB 837661

Basionym: Haplotrichum perseae R.F. Castañeda, Mycotaxon 59: 449. 1996.

Botryobasidium pulchrum (Berk.) G. Langer, comb. nov. MycoBank MB 837662

Basionym: Rhinotrichum pulchrum Berk., J. Linn. Soc., Bot. 13: 175. 1872 "1873".

Botryobasidium pulveraceum (Ellis) G. Langer, comb. nov.

MycoBank MB 837690

Basionym: Monilia pulveracea Ellis, Bull. Washburn Coll. Lab. Nat. Hist. 1: 69. 1884.

Botryobasidium ramosissimum (Berk. \& M.A. Curtis) G. Langer, comb. nov.

MycoBank MB 837866

Basionym: Rhinotrichum ramosissimum Berk. \& M.A. Curtis Grevillea 3(27): 108. 1875.

Botryobasidium sphaerosporum (Linder) G. Langer, comb. nov.

MycoBank MB 837867

Basionym: Oidium sphaerosporum Linder, Lloydia 5: 200. 1942.
Botryobasidium tenerum (Sumst.) G. Langer, comb. nov. MycoBank MB 837691

Basionym: Rhinotrichum tenerum Sumst., Mycologia 3:

51. 1911.

Botryobasidium vesiculosum (Linder) G. Langer, comb. nov.

MycoBank MB 837693

Basionym: Oidium vesiculosum Linder, Lloydia 5: 193. 1942.

Use Bullera Derx 1930 (A) rather than Bulleromyces

Boekhout \& Á. Fonseca 1991 (S)

Bulleromyces albus, type of the monotypic generic name Bulleromyces, was described as the sexual state of Bullera alba, type of the generic name Bullera (Boekhout et al. 1991), thus Bullera and Bulleromyces are synonyms. Bullera is used more widely than Bulleromyces (GSS Bullera $=1230$, Bulleromyces $=129$ ). Given that Bullera has priority, currently includes over 60 species, and is widely used, we recommend the use of Bullera.

Use Chaetospermum Sacc. 1892 (A) rather than Efibulobasidium K. Wells 1975 (S)

Chaetospermum, typified by C. chaetosporum, the name of the original illegitimate name C. tubercularioides (Smith and Ramsbottom 1914; Tangthirasunun et al. 2014), was placed in Sebacinales (Rungjindamai et al. 2008; Oberwinkler et al. 2014). A relationship of Chaetospermum to Efibulobasidium was shown by Wells and Bandoni (2001). Kirschner and Oberwinkler (2009) noted that conidia of $C$. gossypinum were associated with specimens of E. albescens, the type of Efibulobasidium, thus Chaetospermum and Efibulobasidium are most likely synonyms as accepted by Wells and Bandoni (2001) and Crous et al. (2014). In addition, Chaetospermum camelliae was studied by Kirschner et al. (2017) who placed its sexual morph in Efibulobasidium. Thirteen species have been accepted in Chaetospermum while only four names have been described in Ebifulobasidium, one of which has since been transferred to Globulisebacina (Oberwinkler et al. 2014) and two of which are invalid (Kirk 2020). Given its priority, the greater number of species, and more common usage (GSS Chaetospermum $=208$, Efibulobasidium $=83$ ), we recommend the use of Chaetospermum.

\section{Protect Coprinellus P. Karst. 1879 (S) over Ozonium Link} 1809 (A)

The generic name Coprinellus, lectotypified by $C$. deliquescens, was resurrected for a segregate group of approximately 50 species previously placed in 
Coprinus (Redhead et al. 2001a). Many authors consider Coprinellus domesticus to be the sexual morph of Ozonium auricomum, type of the sanctioned generic name Ozonium (Plowright 1901; Buller 1924; Watling 1979). However, Cáceres et al. (2006) state that "it will probably never be possible to decide to which teleomorph belongs the type species Ozonium auricomum" and suggest referring to the asexual morph as "the Ozonium stage". While one could determine the sexual morph of $O$. auricomum with an adequate holotype or lectotype and epitype with an ex-epitype culture, this is not necessary for the purpose of determining the synonymy of the genus Ozonium with Coprinellus. At the least O. auricomum is closely related to $C$. domesticus. Padamsee et al. (2008) demonstrated that C. deliquescens and $C$. domesticus are congeneric, thus Coprinellus and Ozonium are synonyms. Use of Ozonium for species now currently recognized as Coprinellus would not be tenable. Instead, the term "ozonium-like" should be used to describe the asexual morph of species of Coprinellus as suggested by Cáceres et al. (2006). In addition, the generic name Coprinellus is more widely used than Ozonium (GSS Coprinellus $=621$, Ozonium $=98$ ). Given the widespread use of Coprinellus and the many species placed in that genus, it is recommended that Coprinellus be protected.

The generic name Ozonium has also been used for a fungus unrelated to $O$. auricomum, namely the nonsporulating morph of the ascomycete Phymatotrichopsis omnivora (Shear) Hennebert 1973, often listed in the literature as Ozonium omnivorum (Shear 1907). Now placed in Rhizinaceae (Pezizales), Phymatotrichopsis omnivora is an ubiquitous, economically important plant pathogen that causes root rot of alfalfa, cotton, peanut, and pecan as well as diseases of approximately 2000 species of dicotyledonous plants (Marek et al. 2009).

\section{Protect Coprinopsis P. Karst. 1881 (S) over Rhacophyllus Berk. \& Broome 1871 (A/S) and use rather than Zerovaemyces Gorovij (A/S) 1977 or Hormographiella Guarro \& Gené 1992 (A)}

The generic name Coprinopsis, lectotypified by $C$. friesii, is recognized for a group of species segregated from Coprinus and now includes over 100 species (Redhead et al. 2001a). Redhead et al. (2000) discussed in detail the debate over whether Rhacophyllus was based on an asexual or sexual morph and the history of the application of the name. Maniotis (1964) demonstrated that two morphs, a 'Coprinus' and Rhacophyllus represented one taxon. He named the sexual form Coprinus clastophyllus. Based upon morphological similarities to phylogenetetically classified taxa, Redhead et al. (2001a) considered $C$. clastophyllus and $C$. friesii to be congeneric and transferred Coprinus clastophyllus to Coprinopsis, thus Coprinopsis and Rhacophyllus are synonyms. While Coprinopsis is well known, Rhacophyllus has been rarely used (GSS Coprinopsis $=4530$, Rhacophyllus $=45)$. The synonyms Rhacophyllus lilacinus and Coprinopsis clastophylla are currently both in use at a similar low frequency (GSS ca. 20 citations each, some of which are duplicates), and therefore there is no reason not to adopt the earlier name, which we do below. The generic name Hormographiella, typified by $H$. aspergillata, includes three species each isolated from animals or animal products, including humans (Guarro et al. 1992; Surmont et al. 2002). The relationship between the asexual morph $H$. aspergillata and the sexual morph Coprinus cinereus was determined by Gené et al. (1996) and C. cinereus was placed in Coprinopsis by Redhead et al. (2001a). Although Coprinopsis friesii falls in sect. Alachuana and $C$. cinereus in the separate $C$. cinereus clade, both species are confirmed as members of the genus Coprinopsis (Nagy et al. 2013a, b), thus Coprinopsis and Hormographiella are synonyms. Coprinopsis includes over 100 species and is widely known while only three names have been placed in Hormographiella and it is less commonly used (GSS Hormographiella $=302$ ). Zerovaemyces was described with a single species, Z. copriniformis, by Gorovij (1977). This species name is probably synonymous with Rhacophyllus lilacinus. Given that Coprinopsis is widely known and includes many species, we recommend protection of Coprinopsis over Rhacophyllus and use of Coprinopsis rather than Hormographiella and Zerovaemyces.

A new family, Zerovaemycetaceae, was proposed by Gorovij (1977) and competes for use with Psathyrellaceae [see below under Psathyrellaceae for a discussion about this].

The advantages of using the generic name Coprinopsis over the earlier name Pselliophora P. Karst. 1879 were discussed by Redhead et al. (2001b). Ultimately, a proposal to conserve Coprinopsis over Pselliophora was accepted by the NCF (Gams 2005).

\section{New combination:}

Coprinopsis lilacina (Berk. \& Broome) Redhead, comb. nov.

Mycobank MB 838345

Basionym: Rhacophyllus lilacinus Berk. \& Broome, J. Linn. Soc., Bot. 11: 559. 1871.

Synonyms: Coprinus clastophyllus Maniotis, Amer. J. Bot. 51: 491. 1964.

Coprinopsis clastophylla (Maniotis) Redhead et al., Taxon 50: 227. 2001. 
Use Cryptococcus Vuill. 1901 (A) rather than Filobasidiella Kwon-Chung 1976 (S)

The generic name Filobasidiella was described by Kwon-Chung (1976) for the sexual morph of Cryptococcus neoformans, type of Cryptococcus, thus these generic names are synonyms. Cryptococcus neoformans and related species cause serious respiratory diseases of humans and animals that can be fatal for immunocompromised patients (May et al. 2016). More than 300 species had been placed in Cryptococcus but recently Liu et al. (2015) re-circumscribed Cryptococcus to include only ten species placing many names in other genera. All except one of the five names in Filobasidiella are now recognized in Cryptococcus (Kirk 2020; Liu et al. 2015). Given priority, its well-defined generic status, and widespread use especially for the medically important $C$. neoformans, we recommend the use of Cryptococcus.

Use Dacrymyces Nees 1816 (S) rather than Ditiola Fr. 1822 (S), Pionnotes Fr. 1849 (A) or Dacryoscyphus R. Kirschner \& Zhu L. Yang 2005 (A)

The generic name Ditiola Fr. 1822 was accepted over the pre-Friesian Ditiola P. Browne 1756, now regarded as Schizophyllum, as well as by Donk (1958) based on Nannfeldt (1947) and as accepted and explained by McNabb (1966). Ditiola radicata was designated as type of Ditiola by Brongniart (1824). This species was included in a study of Dacrymyces with Ditiola radicata grouping inside Dacrymyces (Shirouzu et al. 2013; Zamora and Ekman 2019), thus Ditiola is a synonym of Dacrymyces. The type specimen of the type of Pionnotes, P. capitata based on Fusarium capitatum, was re-examined by Seifert (2013) and determined to be Dacrymyces chrysospermus. Based on the phylogenetic trees presented by Shirouzu et al. (2007, 2009, 2013), D. chrysospermus is congeneric with the type of Dacrymyces, D. stillatus, thus Pionnotes is another synonym of Dacrymyces. Pionnotes has often been used in regard to species of Fusarium, while Dacrymyces includes over 100 names and is widely used. Phylogenetic studies of Dacrymycetes by Kirschner and Yang (2005), Shirouzu et al. (2009, 2013), and Zamora and Ekman (2020) demonstrated that the type of the asexually typified Dacryoscyphus, D. chrysochilus, grouped together with Dacrymyces subarcticus in Dacrymyces. Dacrymyces includes over 100 names while only three names have been placed in Dacryoscyphus. Unless the genus Dacrymyces is divided into many genera, Dacryoscyphus remains a synonym of Dacrymyces. Among these synonymous generic names, Dacrymyces is the most widely used (GSS Dacrymyces $=1580, \quad$ Ditiola $=363, \quad$ Pionnotes $=458$, Dacryoscyphus $=16$ ). Given its priority, greater number of names, and widespread use, we recommend the use of Dacrymyces.

\section{Use Deconica (W.G. Sm.) P. Karst. 1879 (S) rather than Pseudohelicomyces Garnica \& E. Valenz. 2000 (A)}

Pseudohelicomyces albus, type of the monotypic generic name Pseudohelicomyces, was described for the asexual morph of Psilocybe merdaria (Valenzuela and Garnica 2000), now regarded as Deconica merdaria (Noordeloos 2009). Since then, the generic name Psilocybe has been proposed for conservation with a new type, P. semilanceata, in order to include species that produce psilocybin (Redhead et al. 2007); this proposal was accepted (Norvell 2010) and is included in Appendix III of the ICN (Wiersema et al. 2020). Thus, P. merdaria and other non-hallucinogenic species previously recognized in Psilocybe have been shown to fall outside of the group that includes the conserved type of Psilocybe (Moncalvo et al. 2002). Although the type of Deconica, D. bullacea, has not been sequenced, it is accepted that D. bullacea and D. merdaria are congeneric (Noordeloos 2009), thus Deconica and Pseudohelicomyces are synonyms. Deconica includes 59 names and is widely used $(\mathrm{GSS}=400)$ while monotypic Pseudohelicomyces remains an obscure name $(G S S=21)$. Given these reasons and based on priority, we recommend the use of Deconica.

\section{Protect Dendrocollybia R.H. Petersen \& Redhead 2001 (S) over Tilachlidiopsis Keissl. 1924 (A) and Sclerostilbum Povah 1932 (A)}

The generic name Dendrocollybia is typified by $D$. racemosa, a species previously placed in Collybia (Hughes et al. 2001). The asexual morph of D. racemosa has been recognized in Tilachlidiopsis typified by $T$. racemosa of which Sclerostilbum septentrionale, the type of the monotypic generic name Sclerostilbum, was considered a synonym (Stalpers et al. 1991; Hughes et al. 2001). Thus, the types of the latter two generic names are synonyms of $D$. racemosa and these three generic names are synonyms. Tilachlidiopsis has included diverse species in the Ascomycota and Basidiomycota (Stalpers et al. 1991) and is rarely used for the latter. Hofstetter et al. (2014) showed that Dendrocollybia should be recognized as a distinct genus. Although Tilachlidiopsis has been used more than Dendrocollybia, many of those references are to names now placed in the ascomycete genus Ophiocordyceps (GSS Dendrocollybia $=85$, D. racemosa $=61$, Tilachlidiopsis $=89$, T. racemosa $=23$, Sclerostilbum $=$ 45). Given the widespread use of Dendrocollybia and its distinct morphology, we recommend that Dendrocollybia be protected over Tilachlidiopsis and Sclerostilbum. 
Protect Diacanthodes Singer 1962 (S) over Bornetina L. Mangin \& Viala 1903 (A)

The genus Diacanthodes, typified by $D$. novoguineensis, includes six species with two varieties of tropical fungi (Robledo et al. 2020). The asexual morph of D. novoguineensis was determined to be Bornetina corium in the monotypic genus Bornetina (Fidalgo 1962a, b), thus Diacanthodes and Bornetina are synonyms. Diacanthodes novoguineensis causes a root disease known as phthiriasis of coffee and other tropical hosts (Rajchenberg and Robledo 2013). Diacanthodes is used more frequently $(\mathrm{GSS}=118)$ and includes more species than Bornetina $(\mathrm{GSS}=70)$, thus we recommend Diacanthodes for protection.

Use Ditangium P. Karst. 1867 (A) rather than Craterocolla Bref. 1888 (S) or Poroidea Göttinger ex G. Winter 1885 (A) The connection between Craterocolla, Ditangium and Poroidea was reviewed by Donk $(1962,1966)$ who concluded that they were sexual and asexual morphs of the same species. Craterocolla, typified by C. cerasi, was confirmed as a distinct genus in Sebacinales by Weiss and Oberwinkler (2001). The generic name Ditangium is typified by $D$. insigne of which Craterocolla cerasi is a synonym (Donk 1962; Nag Raj 1978; Malysheva et al. 2019). Nag Raj (1978) included the monotypic Poroidea, typified by $P$. pithyophila, as a synonym of the asexual morph of Craterocolla cerasi. Thus, Craterocolla, Ditangium, and Poroidea are synonyms. Although Craterocolla is more widely used than Ditangium (GSS Craterocolla= 127 , Ditangium $=34$, Poroidea $=8$ ), Ditangium has priority and was recommended for use by Malysheva et al. (2019), and we follow their recommendation.

\section{Protect Echinoporia Ryvarden 1980 (S) over Echinodia Pat.} 1918 (A)

The generic name Echinoporia, typified by E. hydnophora, was described as the sexual morph of Echinodia theobromae, the type of the monotypic genus Echinodia (Ryvarden and Johansen 1980; Ryvarden 1983), thus Echinoporia and Echinodia are synonyms. Echinoporia includes three species and is more commonly used than Echinodia (GSS Echinoporia $=66$, Echinodia $=15$ ). Because it has a greater number of species and has been used in the recent literature (Motato-Vasquez et al. 2015), we recommend the protection of Echinoporia.

\section{Use Femsjonia Fr. 1849 (S) rather than Cerinosterus R.T. Moore 1987 (A)}

The genus Femsjonia is typified by F. luteoalba for which Exidia peziziformis provides an earlier epithet, thus this species is regarded as F. peziziformis (McNabb 1965). The putative asexual morph of $F$. peziziformis (as F. luteoalba) was named by de Hoog (1974) as
Sporothrix luteoalba, and the connection was reiterated by Maekawa (1987) and Middlehoven et al. (2000). When Cerinosterus was described, it was typified by $S$. luteoalba, which was erroneously interpreted as the asexual morph of a Cerinomyces sp. (Moore 1987). We confirm the relationship of Cerinosterus luteoalbus with F. peziziformis based on the $100 \%$ match of a BLAST search of an ITS sequence (MH856312) from an exparatype strain of C. luteoalbus (CBS 208.48) with $F$. peziziformis. Thus, Cerinosterus and Femsjonia are synonyms. Femsjonia includes 12 names while only two names have been placed in Cerinosterus, one of which, C. cyanescens, is now placed in Quambalaria (de Beer et al. 2006). Shirouzu et al. (2009, 2017) demonstrated that $F$. peziziformis groups outside of Dacrymyces and this was confirmed by Zamora and Ekman (2019) who placed Femsjonia in the Dacrymycetaceae. Given its priority, the greater number of names, and greater use (GSS Femsjonia $=175$, Cerinosterus $=71)$, we recommend the use of Femsjonia.

\section{Use Fistulina Bull. 1791 (S) rather than Confistulina Stalpers 1983 (A)}

The asexual morph of Fistulina hepatica, type of Fistulina, was described in the monotypic genus Confistulina typified by C. hepatica (Stalpers and Vlug 1983), thus these generic names are synonyms. Fistulina currently includes 21 names and is widely used (GSS Fistulina= 2900, Confistulina $=23$ ). Given its priority, greater number of species, and its widespread use, Fistulina is recommended for use.

\section{Use Heteroacanthella Oberw. 1990 (S) rather than Acanthellorhiza P. Roberts 1999 (A)}

The monotypic generic name Acanthellorhiza is typified by $A$. globulifera, which is the asexual morph of Heteroacanthella acanthophysa (Roberts 1999). Heteroacanthella is typified by $H$. variabilis (Oberwinkler et al. 1990). Zamora et al. (2014) regarded $H$. acanthophysa and $H$. variabilis as congeneric and added a third species. Heteroacanthella is more widely used than Acanthellorhiza (GSS Heteroacanthella $=35, \quad$ Acanthellorhiza = 4). Heteroacanthella has priority and includes three species, while Acanthellorhiza is monotypic and remains little known, thus we recommend the use of Heteroacanthella.

\section{Use Heterobasidion Bref. 1888 (S) rather than Spiniger Stalpers 1974 (A)}

The holotype of Heterobasidion, H. annosum, is the sexual morph of the type of Spiniger, S. meineckellus (Stalpers 1974), thus these generic names are synonyms. Heterobasidion annosum, often reported as its synonym Fomes annosus, is the cause of a serious tree disease resulting in root and butt rot of pine trees in 
Eurasia, although previously this name had been used to represent a species complex occurring in temperate coniferous forests throughout the world (Ostrosina and Garbelotto 2010; Pegler and Waterston 1968). A number of segregate species have now been described in Heterobasidion (Ostrosina and Garbelotto 2010). Heterobasidion includes about 30 species, has priority, and is well known (GSS Heterobasidion $=14,200$, Spiniger $=5700$ ), while Spiniger includes only one additional species and remains relatively obscure, thus we recommend the use of Heterobasidion.

\section{Use Hohenbuehelia Schultzer 1866 (S) rather than Nematoctonus Drechsler 1941 (A)}

The generic synonymy of Hohenbuehelia, typified by $H$. petaloides, and Nematoctonus, typified by N. tylosporus, was proven by Koziak et al. (2007) in which they showed that Hohenbuehelia-Nematoctonus including their types formed a monophyletic clade in Pleurotaceae. Donk (1962) was the first to designate $N$. tylosporus as the type of Nematoctonus stating that he chose this as the best species to represent the genus. Thorn (2013) made the nomenclatural changes consistent with the recognition of the use of Hohenbuehelia rather than Nematoctonus. Hohenbuehelia produces a mushroom-like sexual morph and is more widely used than the nematode-trapping asexual morph represented by Nematoctonus (GSS Hohenbuehelia $=1500$, Nematoctonus $=564)$. Given that Hohenbuehelia has priority and includes 182 names while Nematoctonus includes only 16 names and in agreement with Thorn (2013), we recommend Hohenbuehelia for use.

\section{Use Leucocoprinus Pat. 1888 (S) rather than Attamyces Kreisel 1972 (A)}

The monotypic generic name Attamyces is typified by $A$. bromatificus, a bromatia-forming fungus associated with attine or leaf-cutter ant nests in the western hemisphere (Kreisel 1972). Attamyces bromatificus was considered to refer to an asexual morph of Leucoagaricus gongylophorus (Chapela et al. 1994; North et al. 1997). Ortiz et al. (2008) analyzed sequences from L. gongylophorus and discussed the taxon under Leucoagaricus, although much earlier the combination Leucocoprinus gongylophorus had been introduced by Heim (1957). Controversy exists over the use of Leucocoprinus and Leucoagaricus. The older name Leucocoprinus is lectotypified by L. cepistipes, while confusion had existed over the type of Leucoagaricus, first validly published by Singer (1948) because he suggested as type an invalid name while including two other validly published names. This dilemma was resolved by Redhead (2016) who lectotypified the generic name Leucoagaricus by L. rubrotinctus, thus overriding the classification of Leucocoprinus americanus as Leucoagaricus americanus by Vellinga (2000). Phylogenetic analyses of DNA sequence data place numerous species of Leucocoprinus and Leucoagaricus, including their types, in the same clade with an intermixing of species from each genus (Vellinga et al. 2011). Despite the evident synonymy of Leucoagaricus with Leucocoprinus, novel species continue to be described in both genera (Ge et al. 2015) pending a comprehensive treatment of the group. For the purpose of placing Attamyces, we treat Leucocoprinus and Leucoagaricus as synonyms with Leucocoprinus having priority. At present, Attamyces should be regarded as a synonym of Leucocoprinus. Given its greater number of names and widespread use, we recommend that Leucocoprinus be used rather than Attamyces.

Coccobotrys is another generic name that has been mentioned as a synonym of members of Agaricaceae such as Leucoagaricus. When introducing Coccobotrys, typified by C. xylophilus, Boudier and Patouillard (1900) noted that the specimen of the type from France differed in some respects from the characteristics of the original description of the basionym Cenococcum xylophilum Fr. 1829. Van Bambeke (1900) reported further material from Belgium, which he regarded as conspecific with the French specimen observed by Boudier and Patouillard (1900). Van Bambeke (1900) considered Coccobotrys xylophilus to be an asexual morph of Lepiota meleagris (now Leucoagaricus meleagris). According to Else C. Vellinga (pers. comm.), the material examined by Boudier and Patouillard (1900) and van Bambeke (1900) is not conspecific with the original collection of Cenococcum xylophilum from Russia. Therefore, the recognition of Coccobotrys as a lepiotaceous fungus is based on a misapplication. The identity of the type of Coccobotrys is unknown. A second species of Coccobotrys, C. chilensis, was transferred to Leucoagaricus by Ruiz and Molinari-Novoa (2016). Note also that Coccobotrys could be confused with the later homonym Coccobotrys R. Chodat 1913, a name applied to a group of algae.

\section{Use Marchandiomyces Diederich. \& D. Hawksw. 1990 (A) rather than Marchandiopsis Ghobad-Nejhad \& Hallenb. 2010 (S)}

Ghobad-Nejhad et al. (2010) demonstrated that the species originally described as Laeticorticium quercinum falls within a clade also containing Marchandiomyces corallinus, an asexual morph that is the type of Marchandiomyces. They chose to place the two species in the same genus, but under the rules of nomenclature at the time, they could not take up Marchandiomyces for the basidiospore-producing $L$. quercinum. Therefore, they introduced Marchandiopsis, typified by L. quercinum. With the move to one fungus-one name, Hawksworth and Henrici (2015) 
argued that Marchandiopsis had rarely been used in comparison to Marchandiomyces and they proposed to take up the latter name. They made the necessary new combination, Marchandiomyces quercinus. Diederich et al. (2018) transferred three other species originally described in Marchandiomyces to Laetisaria, placed Marchandiomyces aurantiacus in Erythricium, and retained three species in Marchandiomyces, including M. quercinus and M. corallinus. Given current usage of Marchandiomyces (GSS Marchandiomyces = 404, Marchandiopsis =9) and in agreement with recent authors, we recommend that Marchandiomyces be used.

\section{Use Mycena (Pers.) Roussel (S) 1806 rather than Decapitatus Redhead \& Seifert (A) 2000}

The generic name Mycena, typified by M. galericulata, is used for over 2000 species of small mushrooms, while the monotypic Decapitatus, typified by D. flavidus based on Stilbum flavidum, was used for the asexual morph of Mycena citricolor (Seifert 1985; Redhead et al. 2000). Several authors have considered $M$. citricolor and $M$. galericulata to be congeneric (Bermudes et al. 1991; Desjardin et al. 2007), thus Mycena and Decapitatus are synonyms. Mycena is more widely used than Decapitatus (GSS Mycena $=$ 11,400, Decapitatus $=243$ ). Given the widespread use of Mycena, the high number of species, and its priority, we recommend Mycena for use when Mycena is adopted wth a broad concept.

Use Myxarium Wallr. 1833 (S) rather than Hyaloria Möller 1895 (S) or Helicomyxa R. Kirschner \& Chee J. Chen 2004 (A) Myxarium nucleatum, the type of Myxarium, and $M$. mesonucleatum were shown to form a strongly supported clade with Hyaloria pilacre, type of the generic name Hyaloria, by Kirschner and Chen (2004), thus Myxarium and Hyaloria are synonyms. They also showed that the type of the monotypic generic name Helicomyxa, $H$. everhartioides, is closely related to $M y x-$ arium. The small conidiomata with conidia of $M$. tremelloides (as Exidia tremelloides) are similar to those of $H$. everhartioides suggesting that these names are synonyms or at least closely related. Thus, the available data suggest that Helicomyxa, Hyaloria, and Myxarium are synonyms. Given the greater number of species, greater use (GSS Myxarium = 213, Hyaloria $=53$, Helicomyxa $=$ 22), and priority, we recommend the use of Myxarium.

\section{New combinations:}

Myxarium everhartioides (R. Kirschner \& Chee J. Chen) R. Kirschner, comb. nov.

MycoBank MB 837868
Basionym: Helicomyxa everhartioides R. Kirschner \& Chee J. Chen, Stud. Mycol. 50: 339. 2004.

Myxarium pilacre (Möller) R. Kirschner, comb. nov. MycoBank MB 837869

Basionym: Hyaloria pilacre Möller, Bot. Mitt. Tropen 8: 173.1895.

\section{Use Necator Massee 1898 (A) over Upasia Harsojo-}

Tjokrosoedarmo \& Rifai 1992 (A/S)

Necator decretus was described as a destructive parasite of young coffee branches in Malaysia (Massee 1898). Rant (1911) connected Necator to an unnamed Corticium and later Rant (1912) connected it to Corticium javanicum and C. salmonicolor (Petch 1912). Most recently the fungus in all stages has been classified as Erythricium salmonicolor (e. g. Moraes et al. 2006) but also has been shown to be an independent sister taxon to Erythricium (Roux and Coetzee 2005; Ghobad-Nejhad et al. 2010; Diederich et al. 2011). In an overlooked publication, Harsojo-Tjokrosoedarmo (1992, 1995) proposed a new genus Upasia for E. salmonicolor. Recognized as a genus separate from Erythricium, Necator has priority and is here recommended for use. A new combination in Necator is required and proposed here.

Erythricium, typified by E. laetum, is considered to be a separate genus that includes as a synonym Marchandiobasidium, typified by $M$. aurantiacum now recognized as Erythricium aurantiacum (Hawksworth and Henrici 2015; Diederich et al. 2018)). Erythricium and its synonym Marchandiobasidium are sexual morph names.

Necator salmonicolor (Berk. \& Broome) K.H. Larss., Redhead, \& T.W. May, comb. nov.

MycoBank MB 838387

Basionym: Corticium salmonicolor Berk. \& Broome, J. Linn. Soc., Bot. 14(74): 71. 1873 "1875".

\section{Protect Neolentinus Redhead \& Ginns 1985 (S) over Digitellus Paulet 1793 (A/S)}

Digitellus humanus, the lectotype of Digitellus, is presumed to be based upon the aborted basidiomes of Neolentinus, most probably N. lepideus (cf. Donk 1962; Redhead and Ginns 1985), which typically do not form expanded pilei but the sterile stipes often become multibranched in complete darkness, such as on supporting timbers in abandoned mine shafts (Vlasenko et al. 2017). Hence, the generic name and species epithet refer to a hand-like form, which have also been named Neolentinus lepideus f. ceratoides based upon Ramaria ceratoides. The validity of the Paulet names and the date of Paulet's 1793 publication have been questioned because of its production during the French revolution and conflicting accounts of its distribution. Presuming the name 
Digitellus published as genus XVI in his index is valid and noting its obscurity, when Neolentinus typified by $N$. kauffmanii includes $N$. lepideus, we recommend that the name Neolentinus should be protected. This is subject to resolution of a proposal to list Paulet's publication as a "Suppressed Work" (Parra et al. 2015).

\section{Use Oliveonia Donk 1958 (S) rather than Oliveorhiza P. Roberts 1998 (A)}

The generic name Oliveonia, typified by O. fibrillosa, was established to replace the later homonym Heteromyces Olive 1957 non Müll. Arg. 1889 (Donk 1958). Although regarded as related to Ceratobasidium, Oliveonia has been shown to be distinct including five species (Kotiranta and Saarenoksa 2005). Oliveorhiza anapauxilla, the type and only species of Oliveorhiza, was described for the asexual morph of Oliveonia pauxilla (Roberts 1998). Oliveonia fibrillosa and O. pauxilla are congeneric (Kotiranta and Saarenoksa 2005; Roberts 1998), thus Oliveonia and Oliveorhiza are synonyms. Oliveonia has been more widely used than Oliveorhiza (GSS Oliveonia $=107$, Oliveorhiza $=6$ ). Given its priority, greater number of species, and widespread use, we recommend the use of Oliveonia.

\section{Use Pleurotus (Fr.) P. Kumm. 1871 (S) rather than Antromycopsis Pat. \& Trab. 1897 (A)}

The generic name Pleurotus is applied to a number of mushroom-forming fungi including the type, $P$. ostreatus, the oyster mushroom, one of the most commonly cultivated edible fungi in the world, and P. eryngii (DC.) Quél. 1872 , the widely consumed king oyster mushroom (Zervakis et al. 2004). Species of Pleurotus are also used industrially to break down aromatic hydrocarbons (Adenipekun et al. 2015); in addition, they can produce toxic compounds that paralyze nematodes. The generic name Pleurotus has already been conserved over six earlier generic names (Wiersema et al. 2020). Miller Jr. (1969) described P. cystidiosus for the sexual morph of Antromycopsis broussonetiae, type of the generic name Antromycopsis. Pleurotus ostreatus and P. cystidiosus were shown to be congeneric by Gonzalez and Labarère (2000), thus Pleurotus and Antromycopsis are synonyms. The genus Pleurotus includes over 500 species names; of these, a few dozen have been wellstudied and are nematophagous (Thorn and Barron 1984; Barron and Thorn 1987), whereas the name Antromycopsis is rarely used and includes only 19 names (GSS Pleurotus = 132,000, Antromycopsis = 175). Considering the widespread use of Pleurotus, its numerous species, its economic importance, and its priority, we recommended the use of Pleurotus.

\section{Use Polyporus P. Micheli ex Adans. 1763 (S) rather than Mycelithe Gasp. 1841 (A)}

The monotypic generic name Mycelithe, typified by $M$. fungifera, accommodates sclerotia of Polyporus tuberaster, lectotype of Polyporus. Donk (1962) provides one of the few references to the obscure generic name Mycelithe. Based on the original well-illustrated publication, Gasparrini (1842) concluded that $M$. fungifera refers to sclerotia of a species in Polyporus, thus these two generic names are synonyms. Polyporus is a widely used name with over 3000 names described in this genus while the monotypic Mycelithe is uncommonly used (GSS Polyporus $=30,100$, Mycelithe $=7$ ). Given its widespread use and priority as well as the numerous described species, we recommend the use of Polyporus.

Controversy exists regarding the typification of the sanctioned name Polyporus. The earliest non-mechanical lectotypification was by Clements and Shear (1931) who selected P. brumalis for "Polyporus (Mich.) Fr. Epicr. 427 1838". However, Fries (1838) considered the generic name to link back to Fries (1821) and consequently Donk (1933) selected P. tuberaster as lectotype from species included by Fries (1821). For the moment, we follow Donk (1933) and current usage by indicating $P$. tuberaster as type of Polyporus, but we note that formal conservation with a conserved type may be required.

\section{Protect Postia Fr. 1874 (S) over Ptychogaster Corda 1838 (A)} Postia, lectotypified by P. lactea, is a well-defined genus as recently circumscribed by Pildain and Rajchenberg (2013) and Shen et al. $(2015,2019)$. Walker (1996) provided an extensive discussion of the validity of the publication of the generic name Postia. The type of Ptychogaster, P. albus, was placed in Postia as P. ptychogaster by Knudsen and Hansen (1996) and is widely reported (Shen et al. 2015; Vampola et al. 2014; Vizzini and Zotti 2008). Given that Postia lactea and P. ptychogaster are congeneric, as demonstrated by Shen et al. (2015), then Postia and Ptychogaster are synonyms. Most names in Ptychogaster are now recognized in Postia or other related genera (Stalpers 2000). Postia is the most widely used of these two names (GSS Postia $=7950$, Ptychogaster $=617$ ), thus we recommend protection and use of the generic name Postia.

Two older synonyms are known for Postia ptychogaster based on Polyporus ptychogaster but neither of these synonyms listed below are widely used. This synonymy has been supported by Shevchenko (2018) and Stalpers (2000), thus we propose the basionym Polyporus ptychogaster for protection:

Polyporus ptychogaster F. Ludw., Z. Gesammten Naturwiss. (Halle) 3: 424. 1880.

Lectotype: See Table 2. 
Accepted name: Postia ptychogaster (F. Ludw.) Vesterh., Nordic J. Bot. 16: 213. 1996.

Rejected synonyms: Ptychogaster albus Corda, Icon. fung. 2: 24. 1838.

Trichoderma fuliginoides Pers., Syn. meth. fung. 1: 231. 1801.

\section{Protect Psathyrellaceae Vilgalys et al. 2001 over Zerovaemycetaceae Gorovij 1977}

Zerovaemyces is regarded as a synonym of Coprinopsis with the type of Zerovaemyces, Z. copriniformis, considered a synonym of Rhacophyllus lilacinus, now Coprinopsis lilacina as discussed above under Coprinopsis. Gorovij (1979) published a new class name, Loculomycetes. Redhead et al. (2000) argued that Zerovaemyces and Zerovaemycetaceae, the latter introduced by Gorovij (1979), were asexual morphs and using the Code in force in 2000-2001, Redhead et al. (2001a) elevated Coprinaceae subfam. Psathyrelloideae Singer to family level with priority based upon the date 2001. Coprinopsis (syn. Zerovaemyces) is classified in the Psathyrellaceae in modern phylogenetic analyses, thus Zerovaemycetaceae is a synonym of Psathyrellaceae. Psathyrellaceae appears in over 1500 GS records while Zerovaemycetaceae appears in 3 GS hits, two of which are Redhead et al. (2000, 2001a). The name Psathyrellaceae is adopted in modern phylogenetic analyses and in mushroom books. It would be disruptive to switch to a family name used so infrequently and based upon synonymized taxon names, thus we propose the name Psathyrellaceae for protection.

\section{Use Rhizoctonia DC. 1815 (A) rather than Thanatephorus Donk 1956 (S)}

The generic name Rhizoctonia has been conserved with $R$. solani as the conserved type and $R$. solani is formally conserved against $R$. napaeae (Stalpers et al. 1998; Wiersema et al. 2020). Rhizoctonia includes many species, especially ones causing plant diseases (Ajayi-Oyetunde and Bradley 2018; Oberwinkler et al. 2013). Some names in Rhizoctonia have been shown to be ascomycetous fungi and removed to Ascorhizoctonia and other genera (Yang and Korf 1985) while others have been transferred to Waitea. By far the most important species is the ubiquitous type $R$. solani, which has been divided into anastomosis groups and causes diseases such as root rot, damping off in seedlings, and leaf and fruit rot of many plant hosts (Gonzales et al. 2016). The sexual morph of $R$. solani was described as Thanatephorus cucumeris, type of the genus Thanatephorus (Roberts 1999), thus Rhizoctonia and Thanatephorus are synonyms. The decision to use Rhizoctonia or Thanatephorus is a difficult one; however, Rhizoctonia is used more commonly albeit in a broad sense and has priority (GSS Rhizoctonia $=22,400$, Thanatephorus $=1930$ ), thus we recommend the use of Rhizoctonia.
See below in regard to species of Rhizoctonia that belong to Waitea.

\section{Protect Riopa D.A. Reid 1969 (S) over Sporotrichum Link 1809 (A)}

The generic name Riopa, previously considered a synonym of Ceriporia, is typified by $R$. davidii, which is regarded as a synonym of the older name $R$. metamorphosa by Miettinen et al. (2016). Based on the concept of Miettinen et al. (2016), the genus includes one additional species R. pudens. The typification of Sporotrichum is complicated. Sporotrichum has been cited as having various types over time, and the type accepted by recent authors, S. aureum Link 1809 (Hughes 1958; Donk 1962; Stalpers 1984; Miettinen et al. 2016), is a homonym of the sanctioned name $S$. aureum (Pers.) Fr. 1832 and thus not available without conservation. Stalpers (1984) and Miettinen et al. (2016) considered $S$. aureum Link 1809 synonymous with S. aurantiacum Fr., which is the asexual morph of $R$. metamorphosa. Although more than 300 names have been placed in Sporotrichum, the majority of these names belong in Ascomycotina. Stalpers (1984) accepted three species in Sporotrichum, each of which has been shown to be phylogenetically distinct, i. e. not congeneric (Miettinen et al. 2016), thus Sporotrichum now includes only the type, S. aurantiacum Fr. 1832, a sanctioned, legitimate, later homonym of $S$. aurantiacum Grev. 1822 based on Mucor aurantius Bull. 1791. We follow Miettinen et al. (2016) and recommend Riopa for protection over Sporotrichum; in addition, we recommend the protection of $R$. metamorphosa over $S$. aurantiacum Fr.

\section{Name proposed for protection:}

Riopa metamorphosa (Fuckel) Miettinen \& Spirin, MycoKeys 17: 27. 2016.

Basionym: Polyporus metamorphosus Fuckel, Jahrb. Nassauischen Vereins Naturk. 27-28: 87. 1874.

Type: see Table 2.

Synonyms to be protected over: Mucor aurantius Bull., Hist. Champ. France 1: 103. V. 1791.

Sporotrichum aurantiacum Fr., Syst. Mycol. 3: 423. 1832, nom. sanct., non Grev., Mem. Wern. Nat. Hist. Soc. 4: 67. 1822.

Protect Scytinostroma Donk 1956 (S) over Michenera Berk. \& M.A. Curtis 1869 (A), Artocreas Berk. \& Broome 1873 (A/ S), and Stereofomes Rick 1928 (S) and use rather than Licrostroma P.A. Lemke 1964 (S)

The sexual morph of Michenera, typified by M. artocreas, was described as Licrostroma, typified by L. subgiganteum, by Lemke (1964). Lyman (1907) had earlier demonstrated that cultures derived from the basidiospores of what he called Corticium subgiganteum, the basionym of L. subgiganteum, produced what he called Michenera spores, but he was unable to induce the cultures to form hymenia and 
basidiospores. Molecular data place $L$. subgiganteum with Scytinostroma aluta and S. portentosum, the type of Scytinostroma (Giraldo et al. 2017; K-H Larsson pers. comm. 2017) and with S. caudisporum (Leal-Dutra et al. 2020). Thus, Scytinostroma, Michenera, and Licrostroma are synonyms. Giraldo et al. (2017) recognized the synonymy of Licrostroma with Michenera but chose to use Licrostroma despite the priority of Michenera. Conversely, Liu et al. (2019) recognized Michenera including a new species; their phylogeny placed both the type and the new species of Michenera in a clade with the type of Scytinostroma, S. portentosum. Although the genus is not monophyletic (Larsson 2007), Scytinostroma currently includes 25 names, one of which was added by Wang et al. (2020). The type of the genus and other species of Scytinostroma with globose basidiospores were placed in "group 1" by Boidin and Lanquetin (1987). To this group these authors also refer Stereofomes nodulosus, the lectotype of Stereofomes selected by Donk (1956), because it was the only species that included a description as later discussed and accepted by Boidin and Lanquetin (1987). They recognized the synonymy of Scytinostroma with Stereofomes and suggested that Scytinostroma should be conserved over Stereofomes, although this was never formally done. Among the 12 names placed in Stereofomes, only four remain in that genus. Of these four synonymous generic names, Scytinostroma is the most well-known (GSS Scytinostroma $=612, \quad$ Licrostroma $=30, \quad$ Stereofomes $=13$, Michenera $=c a 50$, but confused with other meanings of the word). Despite its polyphyletic nature, it seems least disruptive to protect the generic name Scytinostroma for the type $S$. portentosum and its relatives.

A final note is that Artocreas, lectotypified by Artocreas micheneri by Massee (1888), was based on the same find as Michenera artocreas, and may have been an unintentional flipping of the two binomial parts (cf. Donk 1962) but are clearly valid names. Considerable confusion was sown by Berkeley throughout the publication history of Artocreas by one lapsus calami after another. Berkeley in Berkeley and Curtis (1869) first published the name Michenera artocreas. Then he published Artocreas with Artocreas micheneri and A. poriniiforme (Berkeley and Broome 1875). This was followed by an admission of error (Berkeley and Broome 1876) that introduced more errors, namely that Artocreas is the same as Michenera, but he spelled Artocreas in two different ways with two different author citations, namely "Artocreas, B. \& Br." and "Artrocreas, B. \& C.". Massee (1888) further clarified and then muddied the waters by first lectotypifying Artocreas by A. micheneri, then declaring after a long discussion on Artocreas poroniiforme, "Under the circumstances it has been considered advisable to propose the genus Artocreas as the type of a new order, occupying a position exactly intermediate between the Nidulariaceae and the Hymenogastreae". He then proceeds to name a new order Matulales (as Matulea) with a new genus Matula, typified by Matula poroniiforme, and not by Artocreas.

\section{New combinations:}

Scytinostroma artocreas (Berk. \& M.A. Curtis) K.-H. Larss., comb. nov.

MycoBank MB 837870

Basionym: Michenera artocreas Berk. \& M.A. Curtis, J. Linn. Soc., Bot. 10: 333. 1868 "1869”.

Synonyms: Corticium subgiganteum Berk., Grevillea 2(13): 3. 1873.

Licrostroma subgiganteum (Berk.) P.A. Lemke, Canad. J. Bot. 42: 763. 1964.

Artocreas micheneri Berk. \& M.A. Curtis, in Berkeley \& Broome, J. Linn. Soc., Bot. 14: 73. 1873 “1875”.

Aleurodiscus orientalis Lloyd, Mycol. Writ. 6(62): 927. 1920.

Aleurodiscus reflexus Yasuda, Bot. Mag. (Tokyo) 35(420): 269. 1921.

Globuliciopsis lindbladii Hjortstam \& Ryvarden, Syn. Fungorum 22: 19. 2007.

Scytinostroma incrustatum (S.H. He et al.) K.H. Larss., comb. nov.

MycoBank MB 838392

Basionym: Michenera incrustata S.H. He et al., Nova Hedwigia 108: 199. 2018 “2019”.

Scytinostroma nodulosum (Rick) K.H. Larss., comb. nov.

MycoBank MB 837871

Basionym: Stereofomes nodulosus Rick, Egatea 13: 435. 1928.

\section{Use Sistotrema Pers. 1794 (S) rather than Ingoldiella D.E. Shaw 1972 (A)}

In sanctioning Sistotrema, Fries (1821) included only $S$. confluens Pers. 1794, although listing Hydnum sublamellosum Bull. 1787 as a synonym. Persoon (1794) had previously described Sistotrema including S. confluens with Hydnum sublamellosum as a synonym as well as $S$. cinereum and Boletus unicolor. Sistotrema hamatum was described as the sexual morph of Ingoldiella hamatum, the type of Ingoldiella, according to Nawawi and Webster (1982) who obtained both morphs in pure culture from partially submerged decaying leaves collected in a stream in Malaysia. Although S. hamatum has not been sequenced, it has been widely accepted in Sistotrema, as congeneric with Sistotrema confluens, thus Sistotrema and Ingoldiella are synonyms. The large genus Sistotrema is classified in Hydnaceae, Cantharellales, with close relationships to Clavulina, Hydnum, and 
Membranomyces. It is considered polyphyletic (Moncalvo et al. 2006; Bernicchia and Gorjón 2010) or paraphyletic (Larsson 2007). Zhou and Qin (2013) determined that a monophyletic Sistotrema can be divided into subclades that include the type plus 13 members of the genus as well as other genera, however, $S$. hamatum was not included in this study. Sistotrema is more commonly used than Ingoldiella (GSS Sistotrema $=1250$, Ingoldiella $=$ 91) and includes over 200 names while Ingoldiella includes only three names. Given the widespread use of Sistotrema, the greater number of names, and its priority, we recommend the use of Sistotrema.

\section{Use Sterigmatosporidium G. Kraep. \& U. Schulze 1983 (A)} rather than Cuniculitrema J.P. Samp. \& R. Kirschner 2001 (S) Sterigmatosporidium polymorphus, the type and only species in Sterigmatosporidium, was described for a species later determined to be the asexual morph of Cuniculitrema polymorpha, the type and only species of Cuniculitrema (Kirschner et al. 2001), thus these generic names are synonyms. Sterigmatosporidium was initially considered to be related to Sterigmatomyces (Kraepelin and Schulze 1982), the latter genus typified by S. halophilus, and now shown to belong in Pucciniomycotina (Aime et al. 2006, 2018). Liu et al. (2015) included Sterigmatosporidium polymorphus (as Cuniculitrema polymorpha) in their molecular study of Tremellomycetes and placed this species near Fellomyces in Agaricomycotina. Sterigmatosporidium is used more extensively than Cuniculitrema (GSS Sterigmatosporidium =186, Cuniculitrema $=60$ ). Given that both genera are monotypic but Sterigmatosporidium has priority and is more widely used, we recommend the use of Sterigmatosporidium.

\section{Use Subulicystidium Parmasto 1968 (S) rather than Aegeritina Jülich 1984 (A)}

The monotypic Aegeritina is typified by A. tortuosa, now considered a synonym of Subulicystidium longisporum, the type of Subulicystidium (Kendrick and Watling 1979), thus these generic names are synonyms. Because it has priority, includes 11 names, and is widely used (GSS Subulicystidium $=248$, Aegeritina $=19)$, we recommend the use of Subulicystidium.

\section{Use Tomophagus Murrill 1905 (S) rather than}

Thermophymatospora Udagawa, Awao \& Abdullah 1986 (A) The generic name Tomophagus, typified by $T$. colossus, was established for an unusual species often referred to as Ganoderma colossus (Fr.) C.F. Baker 1920. Hong and Jung (2004) were the first to show that G. colossus fell outside Ganoderma. Le et al. (2012) recognized this species in Tomophagus and described a second species of Tomophagus, T. cattienensis. The monotypic Thermophymatospora, typified by $T$. fibuligera, was described for an asexual basidiomycete, which was later determined to be the asexual morph of Tomophagus colossus as G. colossus (Adaskaveg and Gilbertson 1989), thus Tomophagus and Thermophymatospora are synonyms. Given its priority, the greater number of names, widespread use (GSS Tomophagus $=115$, Thermophymatospora 19$)$, and recent study, we recommend the use of Tomophagus.

\section{Use Trechispora P. Karst. 1890 (S) rather than} Osteomorpha Watling \& W.B. Kendr. 1979 (A)

The type of Trechispora, T. onusta, is now regarded as a synonym of $T$. hymenocystis (Larsson 1994). When Watling and Kendrick (1979) validated the name Osteomorpha, typified by $O$. fragilis, they noted its association with Trechispora farinacea, a species name used at that time in a broad sense (Liberta 1973). Since then, a number of authors have suggested that $O$. fragilis is the asexual morph of Trechispora farinacea (Hjortstam et al. 1988; Mel'nik 2011). Later studies have shown that several Trechispora species are associated with an asexual morph similar to Osteomorpha (Larsson 1995; Miettinen and Larsson 2006), although it is most commonly seen with T. stevensonii (Berk. \& Broome) K.H. Larss. 1995. Ordynets et al. (2015) showed that $T$. farinacea and $T$. stevensonii are distinct species and that both resolve within Trechispora together with the type of Trechispora, thus Trechispora and Osteomorpha are synonyms. Trechispora is a widely used genus with over 90 names (GSS Trechispora $=1490$, Osteomorpha $=39$ ) and has priority, while Osteomorpha includes only the type, thus we recommend the use of Trechispora.

Use Trimorphomyces Bandoni \& Oberw. 1983 (S) rather than Anastomyces W.P. Wu et al. \& Gange 1997 (A)

In studying Trimorphomyces typified by T. papilionaceus, Kirschner and Chen (2008) concluded that the type of the monotypic genus Anastomyces, A. microsporus, was the asexual morph of T. papilionaceus, thus Trimorphomyces and Anastomyces are synonyms. Although both generic names include only one species name, Trimorphomyces is used more frequently $(\mathrm{GS}=82)$ than Anastomyces $(\mathrm{GS}=$ 13). Given its priority and more common use, we recommend the use of Trimorphomyces.

Protect Tulasnella J. Schröt. 1888 [June] (S) over Hormomyces Bonord. 1851 (A) and use rather than Prototremella Pat. 1888 [August] (S), Hormisciopsis Sumst. 1914 (A), or Epulorhiza R.T. Moore 1987 (A)

The generic name Tulasnella is typified by T. lilacina, regarded as a synonym of T. violea by Donk (1966), but not by Roberts (1994a, b), and includes 91 names. Hormomyces is typified by $H$. aurantiacus and includes seven names. The latter was often considered 
the asexual morph of Tremella mesenterica following the speculations of Saccardo (1916) and Bresadola (1932). This was never proven experimentally but was broadly accepted (e. g. McNabb 1969). After the cultural studies of $H$. aurantiacus by Tubaki (1976) and the description of the asexual morph of $T$. mesenterica by Pipolla and Kotiranta (2008), it was clear that this putative connection was incorrect. rDNA phylogenies by Mack et al. (2021) suggest that $H$. aurantiacus is a member of the same clade as Tulasnella violea, but is unlikely to be conspecific with it. Hormisciopsis gelatinosa, the only named species in that genus, is likely to be a synonym of Hormomyces aurantiacus. The generic name Prototremella, published in the same year as Tulasnella, is typified by P. tulasnei, now Tulasnella tulasnei (Pat.) Juel 1897. The synonymy of these two generic names and the selection of Tulasnella as the accepted name by Donk (1966) has never been questioned and is supported by Stafleu and Cowan (1976) and the monthly publication dates recorded in the Journal de Botanique. Epulorhiza with seven names is typified by E. repens based on Rhizoctonia repens. Warcup and Talbot (1967) identified the sexual morph of $R$. repens as Tulasnella calospora, with reference to Rogers (1933) and Olive (1957) both of whom used the name $T$. calospora for all Tulasnella collections with spores over $15 \mu \mathrm{m}$ long, regardless of differences in spore shape. Roberts (1994a, b) re-examined type collections of T. calospora and T. deliquescens and distinguished the two species based on spore shape and size, noting that the illustration of "Tulasnella calospora" in Warcup and Talbot (1967) was misnamed and was actually $T$. deliquescens. The name $T$. calospora has continued to be used by many authors for the sexual morph of E. repens. Cruz et al. (2016) and papers cited therein could not resolve the synonymy of T. calospora and T. deliquescens and considered them to be distinct species as does Oberwinkler et al. (2017). Regardless, T. calospora/T. deliquescens and T. violea are congeneric (Cruz et al. 2016; Kristiansen et al. 2001; Moncalvo et al. 2006; Linde et al. 2017), thus Tulasnella and Epulorhiza are synonyms. Many of these species, especially T. calospora/deliquescens, are associated with the roots of orchids (Linde et al. 2017; McCormick et al. 2004; Weiss et al. 2004). Despite Hormomyces being an older name, it has rarely been used in the academic literature (GSS Tulasnella $=1629$, Hormomyces $=42$ ). Similarly, Tulasnella is more widely used than Epulorhiza (GSS = 875) and the two other obscure generic synonyms (GSS Prototremella $=35$, Hormisciopsis $=9$ ). Therefore, we recommend the use of Tulasnella.

Epulorhiza is already considered a taxonomic synonym of Tulasnella and several species, e. g. E. amonilioides and $E$. anaticula, were already transferred to that genus
(Fujimori et al. 2019). The remainder are recombined in Tulasnella below:

\section{New combinations:}

Tulasnella albertensis (Currah \& Zelmer) J. Mack \& P. Roberts, comb. nov.

MycoBank MB 32427

Basionym: Epulorhiza albertensis Currah \& Zelmer, Rep. Tottori Mycol. Inst. 30: 48. 1992.

Tulasnella calendulina (Zelmer \& Currah) J. Mack \& P. Roberts, comb. nov.

MycoBank MB 832428

Basionym: Epulorhiza calendulina Zelmer \& Currah, Canad. J. Bot. 73: 1984. 1995.

Tulasnella epiphytica (O.L. Pereira et al.) J. Mack \& P. Roberts, comb. nov.

MycoBank MB 832427

Basionym: Epulorhiza epiphytica O.L. Pereira et al., Mycoscience 44: 154. 2003.

Tulasnella inquilina (Currah et al.) J. Mack \& P. Roberts, comb. nov.

MycoBank MB 832430

Basionym: Epulorhiza inquilina Currah et al., Mycotaxon 61: 338. 1997.

\section{Protect Typhula (Pers.) Fr. 1818 (S) over Sclerotium Tode 1790 (A)}

The genus Typhula, lectotypified by $T$. phacorrhiza (Donk 1933), includes over 150 species. Typhula was originally published as Clavaria [unranked] Typhula by Persoon (1801) who included six species in the unranked infrageneric taxon. Fries (1818) listed four species when he recognized this taxon at the generic level. Donk (1954) noted that the proposed lectotype of Typhula by Clements and Shear (1931) of T. sclerotioides (Pers.) Fr. 1838 (syn. Phacorhiza sclerotioides Pers. 1822) was ineffective because this species was not included in the protologue or sanctioning work. The genus Sclerotium, typified by $S$. complanatum, was established for fungi producing asexual sclerotia. The typification of Sclerotium is explained by Donk (1962) in which the lectotypification by Clements and Shear (1931) followed by Cooke (1953) is accepted. The name $S$. complanatum is considered to be the asexual morph of T. phacorrhiza (Remsberg 1940), thus Typhula and Sclerotium are synonyms. Recently the diverse phylogenetic affinities of species of Sclerotium have been determined (Xu et al. 2010), many of which are members of Ascomycota. Given the confusion about the phylogeny of species of Sclerotium and the numerous species placed in the relatively well-defined genus Typhula, protection of the generic name Typhula is recommended. 


\section{Protect Typhulaceae Jülich 1982 (S) over Sclerotiaceae} Dumort. 1822 (A)

The type genus of Sclerotiaceae is Sclerotium Tode. Sclerotiaceae was first spelled 'Sclerotaceae' and correctly spelled by Link (1826). The name Sclerotiaceae has fallen out of use as a generalized family name for any sclerotial-based genera whereas the name Typhulaceae is useful for this phylogenetically defined group.

\section{Use Waitea Warcup \& P.H.B. Talbot 1962 (S) rather than} Chrysorhiza T.F. Andersen \& Stalpers 1996 (A) and for some species previously placed in Rhizoctonia

The genus Waitea, typified by W. circinata (Warcup and Talbot 1962), mainly includes pathogens that cause diseases of monocotyledonous plants such as brown ring patch of turfgrasses, sclerotial rot and ear rot of corn, sheath spot of rice, and damping off and root rot of cereals and grasses, which typically occur in temperate regions (Gutierrez et al. 2007; Toda et al. 2007). The monotypic name Chrysorhiza was introduced for Rhizoctonia zeae, the asexual form of Waitea circinata (Stalpers and Andersen 1996), although this has been determined to be incorrect [see below]. Chrysomyxa has been little used (GSS Waitea $=1460$, Chrysorhiza =163), thus we recommend the use of Waitea.

The generic name Rhizoctonia, typified by $R$. solani (Ceratobasidiaceae, Cantharellales), is not congeneric with W. circinata (syn. Rhizoctonia zeae) (Vilgalys and Cubeta 1994), as W. circinata and several invalid names in Rhizoctonia belong in Waitea within Corticiaceae (De Priest et al. 2005; Ghobad-Nejhad et al. 2010). One new combination and three new species in Waitea are established below.

\section{New combination:}

Waitea zeae (Voorhees) J.A. Crouch \& Cubeta, comb. nov.

MycoBank MB 837872

Basionym: Rhizoctonia zeae Voorhees, Phytopathology 24: 1299. 1938.

Synonyms: "Chrysorhiza zeae" (Voorhees) T.F. Andersen \& Stalpers, Rhizoctonia-forming Fungi 58. 1996; nom. inval. (Art. 41.5).

Moniliopsis zeae (Voorhees) R.T. Moore, Mycotaxon 29: 96. 1987.

Rhizoctonia endophytica var. filicata H.K. Saksena \& Vaartaja, Canad. J. Bot. 38: 938. 1960.

"Waitea circinata var. zeae" Toda et al., Plant Disease 89: 536. 2007; nom. inval. (Arts. 39.1, 40.1).

Several studies have shown that Rhizoctonia zeae should be placed in Waitea as a species distinct from W. circinata (Chang and Lee 2016; de la Cerda et al. 2007; Gürkanli et al. 2016; Toda et al. 2005, 2007; Vojvodić et al. 2020); the new combination is therefore made here.

\section{New species: \\ Waitea agrostidis J.A. Crouch \& Cubeta, sp. nov.} MycoBank MB 837874

Synonym: "Waitea circinata var. agrostis" S.J. Kammerer et al., Plant Disease 95: 521. 2011; nom. inval. (Art. 39.1, 40.1).

Diagnosis: Light yellow colony on PDA differs from pinkish-white colonies of $W$. circinata, white-salmon pink colonies of $W$. oryzae, yellow-pink colonies of $W$. prodiga, and orange colonies of W. zeae. Irregularly shaped, dark brown sclerotia differ from pinkish or orange sclerotia of W. circinata, irregular, salmon-pink to orange sclerotia of $W$. oryzae, irregular to spherical salmon to yellow-salmon sclerotia of $W$. prodiga, and the subspheroid, orange sclerotia of $W$. zeae.

Description: Toda et al., J. Gen. Plant Path. 73: 385. 2007.

Type: Illustration in J. Gen. Plant Path. 73: 383, fig. 1, 2007 (holotype) based on an unspecified collection made in Japan. Representative sequence: GenBank AB213567 (ITS) derived from a collection: Japan, Aichi, on Agrostis stolonifera L. var. palustris, June 1999, isolate NUK-3BG (deposition unknown).

An unidentified Rhizoctonia sp. was found causing a destructive new disease affecting Agrostis stolonifera and Poa pratensis turfgrasses in Japan; the disease is referred to as Waitea reddish-brown patch disease (Toda et al. 2007). Later authors referred to this Rhizoctonia sp. as "Waitea circinata var. agrostis" but the name was not validly published (Kammerer et al. 2011). Phylogenetic relationships based on DNA sequences show that this fungus is a member of the genus Waitea as a species distinct from $W$. circinata and other species in the genus (Kammerer et al. 2011; Toda et al. 2007), thus this new species is described here. Isolates utilized by Toda et al. (2007) could not be located, therefore an illustration is designated as the type and a reference sequence is selected from those obtained by Toda et al. (2007).

Waitea oryzae J.A. Crouch \& Cubeta, sp. nov. MycoBank MB 837881

Synonyms: "Rhizoctonia oryzae" Ryker \& Gooch, Phytopathology 28: 238. 1938; nom. inval. (Art. 39.1).

"Waitea circinata var. oryzae" Toda et al., Plant Disease 89: 536. 2007; nom. inval. (Arts 39.1, 40.1).

Diagnosis: White to salmon pink colony on PDA differs from pale yellow colonies of $W$. agrostidis, pinkish-white colony of $W$. circinata, yellowish pink colony of $W$. prodiga, and orange colony of $W$. zeae. Irregularly shaped, salmon-pink to orange sclerotia 
differ from irregular, dark brown sclerotia of $W$. agrostidis, pinkish or orange sclerotia of W. circinata, irregular to spherical, salmon to yellow-salmon sclerotia of $W$. prodiga, and subspheroid, orange sclerotia of W. zeae.

Description: Ryker \& Gooch, Phytopathology 28: 238. 1938; as "Rhizoctonia oryzae".

Type: USA: Louisiana: Crowley: on stems of Oryza sativa, 22 Jul. 1938, T.C. Ryker 3049 (BPI 455795 - holotype). Representative sequence: GenBank AB213589 (ITS) derived from a collection: Japan, Toyama, on Oryza sativa, isolate RoTTS (deposition unknown).

Rhizoctonia oryzae and W. circinata var. oryzae are invalid names used by plant pathologists to refer to the causal agent of leaf and sheath spots of grasses and cereals. Although neither of these two names were validly published, there is no doubt that this fungus is congeneric with $W$. circinata and distinct from other species in the genus (Chang and Lee 2016; de la Cerda et al. 2007; Gürkanli et al. 2016; Kammerer et al. 2011; Leiner and Carling 1994; Ryker and Gooch 1938; Sharon et al. 2006; Toda et al. 2005, 2007). Therefore, the new species $W$. oryzae is formally established here. The original collection made by Ryker and Gooch (1938) held by BPI has been chosen as the type specimen. In the absence of a sequence from the type, one of the five sequences included by Toda et al. (2007) under $R$. circinata var. ory$z a e$ is indicated as a reference sequence.

Waitea prodiga J.A. Crouch \& Cubeta, sp. nov.

MycoBank MB 837883

Synonym: "Waitea circinata var. prodiga" S.J. Kammerer et al., Plant Disease 95: 521. 2011; as 'prodigus'; nom. inval. (Arts 39.1, 40.1).

Diagnosis: Yellow-pink colony on PDA differs from pale yellow colony of $W$. agrostidis, dark brown colony of $W$. circinata, white-salmon pink colony of $W$. oryzae, and orange colony of W. zeae. Irregular to spherical, salmon to yellowish salmon sclerotia differ from irregular, dark brown sclerotia of $W$. agrostidis, pinkish or orange sclerotia of $W$. circinata, irregular, salmon pink to orange sclerotia of $W$. oryzae, and subspheroid, orange sclerotia of W. zeae.

Description: Kammerer et al., Plant Disease 95: 521. 2011.

Type: Illustration in Plant Disease 95: 517, fig. 2a, 2b (second sclerotium from left), 2011 (holotype), based on the collection: USA: Florida: Fort Myers, on leaves of Paspalum vaginatum 'Sea Dwarf', 4 Jan. 2008, S.J. Kammerer 44 SK-PSA-TM4 (ITS GenBank HM597146).

Waitea circinata var. prodiga was proposed as the name of a novel fungal pathogen responsible for a basal rot disease first identified from Paspalum vaginatum (Kammerer et al. 2011). The name was not validly published, but the phylogenetic relationship of this organism with other species of Waitea and distinctive morphological characters support the separation of $W$. prodiga from other species in the genus. Therefore, Waitea prodiga is here formally established as a new species. Isolates used by Kammerer et al. (2011) were not lodged in a reference collection, therefore an illustration is designated as the type, and a reference sequence is selected from those obtained by Kammerer et al. (2011).

\section{Protect Wolfiporia Ryvarden \& Gilb. 1984 (S) over Gemmularia Raf. 1819 (A), Pachyma Fr. 1822 (A), and Tucahus Raf. 1830 (A)}

The generic name Wolfiporia, typified by W. cocos, was established for the fungus known as tuckahoe or Poria cocos, common throughout North America and regarded as the fungus used medicinally in Asia (Wang et al. 2013). A sclerotial morph of this fungus was described as Sclerotium cocos and placed in Pachyma as P. cocos, type of that genus, as typified and explained by Donk (1962). Although he chose the first species listed, he supports this decision citing that it was based on "a statement by Fries himself ... under Pachyma ..." . Wolfiporia was typified by Poria cocos F.A. Wolf, a now conserved name with a conserved type. Had it not been conserved, Poria cocos would, under Art. F. 8, be typified by the type of Sclerotium cocos. An earlier epithet for the sexual morph was discovered for this species, namely $W$. extensa (Ginns and Lowe 1983); however, prior to changes in the Code permitting one name for each fungus, Redhead and Ginns (2006) proposed to conserve the commonly used name Poria cocos. This was recommended for approval (Norvell 2008) and is now conserved (Wiersema et al. 2020). Wolfiporia itself is not conserved and is a later synonym of the sanctioned names Gemmularia and Pachyma. Wu et al. (2020) resurrected the generic name Pachyma, placing into synonymy the name Wolfiporia. They also distinguished between the commercially important eastern Asian cultivated fungus, formerly classified as Poria cocos or Wolfiporia cocos, and the North American fungi under those names. Wu et al. (2020) adopted the sanctioned name Pachyma hoelen Fr. for the commercial fungus in Asia. However, because they used a secondary source using an older Code, they overlooked the fact that the also sanctioned generic name Gemmularia predates Pachyma. They listed it as "Gemmularia Raf. per Steud." dating from 1824 taken from Donk (1962) who was using a Code recognizing a starting date of 1821 for most fungi. In that same publication, Donk (1962) lectotypified Gemmularia with G. rugosa Raf. The latter species was said to be the tuckahoe of North America (Rafinesque 1819). Donk (1962) questioned whether Gemmularia was accepted taxonomically by Fries $(1823,1832)$, which would mean the name is not sanctioned, but this 
argument is not currently accepted. Additionally, Fries (1832), while having the name Gemmularia typeset in smaller letters, nonetheless gave a direct reference to the page of his 1823 volume, which he did not do for other generic names he did not recognize. We conclude that Gemmularia like Pachyma is sanctioned. Rafinesque (1830) published yet another generic name, Tucahus, citing Gemmularia and the two species that he included in Gemmularia, but only describing $T$. rugosus.

While seven names have been placed in Wolfiporia, Lindner and Banik (2008) demonstrated that W. dilatohypha is not congeneric with $W$. cocos with the former species placed basal to Laetiporus. Only five names have been introduced in Pachyma, of which three (P. cocos, P. hoelen and $P$. pseudococos) relate to currently accepted species, while Pachyma tuber-regium is the sclerotial state of Pleurotus tuber-regium and Pachyma woermannii was introduced for the sclerotium of Lentinus woermannii, which is considered by Pegler (1983) to be a synonym of Pleurotus tuber-regium (as Lentinus tuber-regium). Wolfiporia is more widely used than Pachyma (GSS Wolfiporia $=2040$, Pachyma $=479$, Gemmularia $=8$, Tucahus $=3$ ) and the other names remain obscure. More recently, the entire genome of Wolfiporia cocos was sequenced and all sequences deposited under this name (Lee et al. 2019). Given its greater use and greater number of names, we recommend Wolfiporia for protection.

New combination:

Wolfiporia hoelen (Fr.) Y.-C. Dai \& V. Papp, comb. nov.

Basionym: Pachyma hoelen Fr., Syst. Mycol. (Index): 125. 1832, nom. sanct.

MycoBank MB 838346

\section{Additional names to be protected:}

Protect Phanerochaete chrysosporium Burds. 1974 (S) over Sporotrichum pruinosum Gilman \& E.V. Abbott 1927 (A)

Type: See Table 2.

Phanerochaete chrysosporium is widely known for its industrial use as a white rot fungus that breaks down the aromatic polymer lignin and thus is important in the degradation of wood products (Kersten and Cullen 2007; Matityahu et al. 2015). Recently, Phanerochaete chrysosporium was confirmed as a member of the genus Phanerochaete s. str. (Floudas and Hibbett 2015). The older names Sporotrichum pruinosum and S. pulverulentum have been regarded as the asexual morph of this species either as one or two species (Burdsall Jr and Eslyn 1974; Burdsall Jr 1985). James et al. (2011) concluded that $S$. pulverulentum was distinct from $S$. pruinosum with the later linked to and providing an earlier name for P. chrysosporium. Given its widespread use and importance to applied microbiology, the name $P$. chrysosporium is proposed for protection.
Protect Polyporus mylittae Cooke \& Massee 1892 (S) over Mylitta australis Berk. 1839 (A)

Type: See Table 2.

The genus Mylitta Fr. 1825 is of uncertain application, but has been used for various growths, at least some of which were fungal sclerotia. Mylitta australis was introduced by Berkeley (1839) for the large sclerotia produced by a polypore later described from sporophores as Polyporus mylittae (Cooke 1892). The connection was explicitly made in the protologue of the latter where it was stated that the sporophores of $P$. mylittae were 'growing on Mylitta australis' (Cooke 1892). All subsequent authors including Cunningham (1965) have accepted $M$. australis as synonymous with P. mylittae. Núñez and Ryvarden (1995) expanded the circumscription of Laccocephalum McAlpine \& Tepper, typified by L. basilapidoides McAlpine \& Tepper, to include several other sclerotium-forming austral polypores, specifically Laccocephalum mylittae (Cooke \& Massee) Núñez \& Ryvarden based on $P$. mylittae. This species produces large sporophores after wildfires and has been frequently recorded from across Australia as both Polyporus and Laccocephalum, under the epithet mylittae, including as a target species for the Fungimap mapping scheme (Grey and Grey 2005). In Polyporus, the epithet australis is pre-occupied by Polyporus australis Fr. 1828, now Ganoderma australe (Fr.) Pat., but there is no such obstacle to the transfer of M. australis to Laccocephalum. However, the name $M$. australis has only ever been applied to the sclerotium, and little used since the discovery of the sporophores more than a century ago. Therefore, $P$. mylittae is proposed for protection over M. australis to allow the continued use of L. mylittae.

Acknowledgements

We are grateful for the assistance of Jacqueline Edwards (VPRI), Asa Krys (UPS), Beatriz Ortiz-Santana (CFMR), and Michael Priest (DAR) in locating type specimens. In addition, we thank W. Cavan Allen and Kathleen Herr (BPI) and Viacheslav Spirin $(H)$ for help in locating literature and Else D. Vellinga (University of California at Berkeley) for advice on Coccobotrys.

Adherence to national and international regulations Not applicable.

Authors' contributions

A.Y. Rossman initiated the manuscript and solicited input from all authors. T. May and S. Redhead provided nomenclatural advice about original publication information. They and the remaining authors provided input on the genera that applied to their specialities. The authors read and approved the final manuscript.

Funding

No funding for this project was obtained.

Availability of data and materials

No original data was obtained for this project. 


\section{Declarations}

\section{Ethics approval and consent to participate}

Not applicable, no humans, human subjects nor data were used in this study.

\section{Consent for publication}

Not applicable.

\section{Competing interests}

The authors declare that they have no competing interest.

\section{Author details}

${ }^{1}$ Baarn, The Netherlands. ${ }^{2}$ Ottawa Research and Development Centre, Science and Technology Branch, Agriculture and Agri-Food Canada, CEF, Ottawa, Ontario K1A OC6, Canada. ${ }^{3}$ Royal Botanic Gardens Victoria, 100 Birdwood Avenue, Melbourne, Victoria 3004, Australia. ${ }^{4}$ Department of Botany and Plant Pathology, Oregon State University, Corvallis, OR 97331, USA. ${ }^{5}$ USDA-ARS, Mycology \& Nematology Genetic Diversity \& Biology Laboratory, Beltsville, MD 20705, USA. ${ }^{6}$ Department of Entomology and Plant Pathology, North Carolina State University, Raleigh, NC 27606, USA. ${ }^{7}$ Beijing Advanced Innovation Center for Tree Breeding by Molecular Design, Beijing Forestry University, Beijing, China. ${ }^{8}$ Department of Biomedical Sciences and Engineering, National Central University, Zhongli District, Taoyuan City 320, Taiwan, Republic of China. ${ }^{9}$ Department of Forest Protection, Northwest German Forest Research Institute (NW-FVA), 37079 Goettingen, Lower Saxony, Germany. ${ }^{10}$ Natural History Museum, University of Oslo, Blindern, 0318 Oslo, Norway. ${ }^{11}$ Pacific Northwest Mycology Service, Portland, OR 97229, USA. ${ }^{12}$ Lehrstuhl für Spezielle Botanik und Mykologie, Botanisches Institut, Universität, Auf der Morgenstelle 1, 72076 Tübingen, Germany. ${ }^{13}$ Department of Botany, Institute of Agronomy, Hungarian University of Agriculture and Life Sciences, Budapest, Hungary. ${ }^{14}$ Powys, Wales, UK. ${ }^{15}$ Centro Forestal CIEFAP, C.C. 14, 9200 Esquel, Chubut, Argentina. ${ }^{16}$ National Research Council of Argentina (CONICET), Buenos Aires, Argentina.

${ }^{17}$ Department of Biology, Carlton University, Ottawa, Ontario K1S 5B6, Canada. ${ }^{18}$ Department of Biology, The University of Western Ontario, London, Ontario N6A 5B7, Canada.

\section{Received: 8 November 2020 Accepted: 3 April 2021}

\section{Published online: 11 August 2021}

\section{References}

Abdullah SK, Taj-Aldeen SJ (1989) Extracellular enzymatic activity of aquatic and aero-aquatic conidial fungi. Hydrobiologia 174:217-223

Adams GC, Kropp BR (1996) Athelia arachnoidea, the sexual morph of Rhizoctonia carotae, a pathogen of carrot in cold storage. Mycologia 88:459-472

Adaskaveg JE, Gilbertson RL (1989) Cultural studies of four North American species in the Ganoderma lucidum complex with comparisons to G. lucidum and G. tsugae. Mycological Research 92:182-191

Adenipekun CO, Ipeaiyeda AR, Olayonwa AJ, Egbewale SO (2015) Biodegradation of polycyclic aromatic hydrocarbons (PAHs) in spent and fresh cutting fluids contaminated soils by Pleurotus pulmonarius (Fries) Quelet and Pleurotus ostreatus (Jacq.) Fr. P. Kumm. African Journal of Biotechnology 14:661-667

Aime MC, Castlebury LA, Abbasi M, Bergerow D, Berndt et al (2018) Competing sexual and asexual generic names in Pucciniomycotina and Ustilaginomycotina (Basidiomycota) and recommendations for use. IMA Fungus 9:75-90

Aime MC, Matheny PB, Henk DA, Frieders EM, Nilsson RH et al (2006) An overview of the higher-level classification of Pucciniomycotina based on combined analyses of nuclear large and small subunit rDNA sequences. Mycologia 98:896-905

Ajayi-Oyetunde OO, Bradley CA (2018) Rhizoctonia solani: taxonomy, population biology and management of rhizoctonia seedling disease of soybean. Plant Pathology 67:3-17

Baroni TJ, Franco-Molano AE, Lodge DJ, Lindner DL, Horak E et al (2007) Arthromyces and Blastosporella, two new genera of conidia-producing lyophylloid agarics (Agaricales, Basidiomycota) from the neotropics. Mycological Research 111:572-580

Barron GL, Thorn RG (1987) Destruction of nematodes by species of Pleurotus. Canadian Journal of Botany 64:774-778
Berkeley MJ (1839) Contributions towards a flora of Van Diemen's Land; from collections sent by R.W. Lawrence and Ronald Gunn, Esqrs., to Sir W.J. Hooker. Annals of Natural History 3:322-327

Berkeley MJ, Broome CE (1875) Enumeration of the fungi of Ceylon. Part II., containing the remainder of the Hymenomycetes, with the remaining established tribes of fungi. Journal of the Linnean Society 14:29-140

Berkeley MJ, Broome CE (1876) Supplement to the enumeration of the fungi of Ceylon. Journal of the Linnean Society 15:82-86

Berkeley MJ, Curtis MA (1869) Fungi Cubenses (Hymenomycetes). Journal of the Linnean Society 10:280-342

Bermudes D, Boraas E, Nealson KH (1991) In vitro antagonism of bioluminescent fungi by Trichoderma harzianum. Mycopathologia 115:19-29

Bernicchia A, Gorjón SP (2010) Corticiaceae s.l. Fungi Europaei n 12. Edizioni Candusso 2010, Italia, p 1008

Bien S, Damm U (2020) Prunus trees in Germany-a hideout of unknown fungi? Mycological Progress 19:667-690

Binder M, Hibbett DS (2002) Higher-level phylogenetic relationships of Homobasidiomycetes (mushroom-forming fungi) inferred from four rDNA regions. Molecular Phylogenetics and Evolution 22:76-90

Boekhout T, Fonseca Á, Batenburg-van der Vegte WH (1991) Bulleromyces genus novum (Tremellales), a teleomorph for Bullera alba, and the occurrence of mating in Bullera variabilis. Antonie Van Leeuwenhoek 59:81-93

Boidin J, Lanquetin P (1987) Le Genre Scytinostroma Donk, Basidiomycètes, Lachnocladiaceae. Bibliotheca Mycologica 114:1-130

Boudier E, Patouillard N (1900) Note sur deux champignons hypogés: Coccobotrys xylophilus et Lilliputia gaillardii. Bulletin de la Société mycologique de France 16:141-146

Braun U (2013) (2210-2232) Proposals to conserve the teleomorph-typified name Blumeria against the anamorph-typified name Oidium and twenty-two teleomorph-typified powdery mildew species names against competing anamorph-typified names (Ascomycota: Erysiphaceae). Taxon 62:1328-1331

Bresadola G (1932) Iconographia mycologica. Società Botanica Italiana 23:1100-1150

Brongniart A (1824) Aegerita. In: Levrault FG (ed) Dictionnaire des sciences naturelles, vol 33, p 512

Brongniart A (1825) Essai d'une classification naturelle des champignons, F.G. Levrault, Paris

Buller AHR (1924) Researches on fungi. III. The production and liberation of spores in Hymenomycetes and Uredineae. Hafner Publishing Co., New York

Burdsall HH Jr (1985) A contribution to the taxonomy of the genus Phanerochaete (Corticiaceae, Aphyllophorales). Mycologia Memoirs 10:1-165

Burdsall HH Jr, Eslyn WE (1974) A new Phanerochaete with a Chrysosporium imperfect state. Mycotaxon 1:123-133

Cáceres O, Kirschner R, Piepenbring M, Schofer H, Gené J (2006) Hormographiella verticillata and an Ozonium stage as anamorph of Coprinellus domesticus. Antonie Van Leeuwenhoek 89:79-90

Chang T, Lee YS (2016) Occurrence of brown blight caused by Waitea circinata var. zea on cool season turfgrass in Korea. Mycobiology 44:330-334

Chapela IH, Rehner SA, Schultz TR, Mueller UG (1994) Evolutionary history of the symbiosis between fungus-growing ants and their fungi. Science 266:1691-1695

Clements FE, Shear CL (1931) The genera of fungi. H.W. Wilson Co, New York

Cooke MC (1892) Australian fungi. Supplement to handbook. Grevillea 21:35-39

Cooke WB (1953) The genera of Homobasidiomycetes (exclusive of the Gasteromycetes). Division of Mycology and Disease Survey, US Department of Agriculture, Beltsville [Special publication]

Crous PW, Giraldo A, Hawksworth DL, Robert V, Kirk PM et al (2014) The genera of fungi: fixing the application of type of generic names. IMA Fungus 5:141-160

Cruz D, Suárez JP, Piepenbring M (2016) Morphological revision of Tulasnellaceae, with two new species of Tulasnella and new records of Tulasnella spp. for Ecuador. Nova Hedwigia 102:279-338

Cunningham GH (1965) In: Owen RE (ed) Polyporaceae of New Zealand, vol 164. Bulletin of the New Zealand Department of Scientific and Industrial Research, Wellington, pp 1-304

Cunningham GH (1956) Thelephoraceae of New Zealand. Part IX. The genus Stereum. Part X. The genera Cytidia and Aleurocystis. Part XI. The genus Aleurodiscus. Transactions of the Royal Society of New Zealand 84:201-268

Daniel H-M, Lachance M-A, Kurtzman CP (2014) On the reclassification of species assigned to Candida and other ascomycetous yeast genera based on phylogenetic circumscription. Antonie Van Leeuwenhoek 10: 67-84 
De Beer W, Begerow D, Bauer R, Pegg G, Wingfield MJ (2006) Quambalariaceae fam. nov., a new family in the Microstromatales to accommodate Quambalaria species. Studies in Mycology 55:289-298

De Beer ZW, Seifert KA, Wingfield MJ (2013) A nomenclator for ophiostomatoid genera and species in the Ophiostomatales and Microascales. CBS Biodiversity Series 12:245-322

De Hoog GS (1974) The genera Blastobotrys, Sporothrix, Calcarisporium and Calcarisporiella gen. nov. Studies in Mycology 7:1-84.

de la Cerda KA, Douhan GW, Wong FP (2007) Discovery and characterization of Waitea circinata var. circinata affecting annual bluegrass from the western United States. Plant Disease 91:791-797

De Priest PT, Sikaroodi M, Lawrey JD, Diederich P (2005) Marchandiomyces lignicola sp. nov. shows recent and repeated transition between a lignicolous and a lichenicolous habit. Mycological Research 109:57-70

De Vries RP, de Lange ES, Wösten HAB, Stalpers JA (2008) Control and possible applications of a novel carrot-spoilage basidiomycete, Fibulorhizoctonia psychrophila. Antonie Van Leeuwenhoek 93:409-413

Desjardin DE, Capelari M, Stevani C (2007) Bioluminescent Mycena species from São Paulo, Brazil. Mycologia 99:317-331

Diederich P, Lawrey JD, Sikaroodi M, Gillevet PM (2011) A new lichenicolous teleomorph is related to plant pathogens in Laetisaria and Limonomyces (Basidiomycota, Corticiales). Mycologia 103:525-533

Diederich P, Zimmermann E, Sikaroodi M, Ghobad-Nejhad M, Lawrey JD (2018) A first lichenicolous Corticium species (Corticiaceae, Corticiales), described from Thamnolia in Switzerland. Bulletin de la Société des Naturalistes Luxembourgeois 120:49-56

Donk MA (1933) Revision der niederländischen HomobasidiomycetaeAphyllophoraceae II. Mededeelingen van de Nederlandsche Mycologische Vereeniging 9:1-278

Donk MA (1949) New and revised nomina generica conservanda proposed for Basidiomycetes (Fungi). Bulletin du Jardin Botanique de Buitenzorg III 18:83-168

Donk MA (1954) The generic names proposed for Hymenomycetes. III. "Clavariaceae". Reinwardtia 2:441-493

Donk MA (1956) The generic names proposed for Hymenomycetes. VII Thelephoraceae. Taxon 6:106-123

Donk MA (1958) The generic names proposed for Hymenomycetes. VIII: Auriculariaceae, Septobasidiaceae, Tremellaceae, Dacrymycetaceae (continued). Taxon 7:164-178

Donk MA (1962) The generic names proposed for Hymenomycetes. XII. Deuteromycetes. Taxon 11:75-104

Donk MA (1966) Check list of European hymenomycetous Heterobasidiae. Persoonia 4:145-244

Fidalgo O (1962a) Anatomical observations on the genus Bornetina Mangin \& Viala. Rickia 1:139-143

Fidalgo O (1962b) Type studies and revision of the genus Diacanthodes Sing. Rickia 1:145-143

Floudas D, Hibbett DS (2015) Revisiting the taxonomy of Phanerochaete (Polyporales, Basidiomycota) using a four gene dataset and extensive ITS sampling. Fungal Biology 119:679-719

Fox RTV (2000) Armillaria root rot: biology and control of honey fungus. Intercept, Andover

Fries EM (1818) Observations mycologicae, vol 1, Copenhagen

Fries EM (1821) Systema mycologicum, vol 1, Lund

Fries EM (1823) Systema mycologicum, vol 2(2), Lund

Fries EM (1832) Index Alphabeticus Generum, Specierum et Synonymorum in Eliae Fries Systemate Mycologico ejusque Supplemento "Elencho Fungorum" Enumeratorum

Fries EM (1838) Epicrisis Systematis mycologici. Uppsala

Fujimori S, Junichi PA, Izumi O, Yuichi Y (2019) Three new species in the genus Tulasnella isolated from orchid mycorrhiza of Spiranthes sinensis var. amoena (Orchidaceae). Mycoscience 60:71-81

Fukuda M, Nakashima E, Hayashi K, Nagasawa E (2003) Identification of the biological species of Armillaria associated with Wynnea and Entolome abortivum using PCR-RFLP analysis of the intergenic region (IGR) of ribosomal DNA. Mycological Research 107:1435-1441

Gams W (2004) Report of the committee for fungi: 11. Taxon 53:10671069

Gams W (2005) Report of the committee for fungi: 12. Taxon 54:520-522

Gasparrini G (1842) Ricerche sulla natura della pietra fungaja e sul fungo vi sopranasce. Atti della Accademia Pontaniana 2:197-254 Tav. I-V
Ge Z-W, Yang ZL, Qasim T, Nawaz R, Khalid AN et al (2015) Four new species in Leucoagaricus (Agaricaceae, Basidiomycota) from Asia. Mycologia 107:1033-1044

Gené J, Guillamon JM, Guarro J, Pujol I, Ulfig K (1996) Molecular characterization, relatedness and antifungal susceptibility of the basidiomycetous Hormographiella species and Coprinus cinereus from clinical and environmental sources. Antonie Van Leeuwenhoek 70:49-57

Ghobad-Nejhad M, Nilsson RH, Hallenberg N (2010) Phylogeny and taxonomy of the genus Vuilleminia (Basidiomycota) basedon molecular and morphological evidence, with new insights into Corticiales. Taxon 59:1519-1534

Ginns J, Lowe JL (1983) Macrohyporia extensa and its synonym Poria cocos. Canadian Journal of Botany 61:1672-1679

Giraldo A, Crous PW, Schumacher RK, Cheewangkoon R, Ghobad-Nejhad M et al (2017) The genera of Fungi-G3: Aleurocystis, Blastacervulus,

Clypeophysalospora, Licrostroma, Neohendersonia and Spumatoria. Mycological Progress 16:325-348

Gonzales D, Rodriguez-Carres M, Boekhout T, Stalpers J, Kuramae EE et al (2016) Phylogenetic relationships of Rhizoctonia fungi within the Cantharellales. Fungal Biology 120:603-619

Gonzalez P, Labarère J (2000) Phylogenetic relationships of Pleurotus species according to the sequence and secondary structure of the mitochondrial small-subunit rRNA V4, V6 and V9 domains. Microbiology 146:209-221. https://doi.org/10.1099/00221287-146-1-209 PMID 10658667

Gorovij LF (1977) Loculous type of sex sporogenesis in Hymenomycetes. Dopovidi Akademiï Nauk Ukrains'koi RSR Seriya B 39:742-746 [In Ukranian]

Gorovij LF (1979) Ontogenesis of fruit bodies of Zerovaemyces copriniformis Gorovoy-a representative of a new class of Loculomycetes. Ukrayins'kyi Botanichnyi Zhurnal 36:4-47 [In Ukranian]

Grey P, Grey E (2005) Fungi down under: the Fungimap guide to Australian fungi. Fungimap, South Yarra

Guarro J, Gené J, De Vroey C, Gueho E (1992) Hormographiella; a new genus of hyphomycetes from clinical sources. Mycotaxon 45:179-190

Gürkanli CT, Aydin EB, Demirci E, Erper I, Karaca B et al (2016) 18S rDNA AND $\beta$-tubulin diversity in Rhizoctonia zeae Voorhees. Pakistani Journal of Botany 48:645-651

Gutierrez SA, Cundom MA, Gasoni L, Barrera V (2007) First record of Rhizoctonia zeae on corn in Argentina. Australasian Plant Disease Notes 2:137-138

Harsojo-Tjokrosoedarmo A (1992) The taxonomy of Corticium salmonicolor. IImu Pertanian (Agricultural Science) 5:565-570

Harsojo-Tjokrosoedarmo A (1995) Various stages of pink fungus (Upsaia salmonicolor) in Java. Indonesian Journal of Plant Protection 1:19-27

Hawksworth DL, Henrici A (2015) New resting places for Laeticorticium quercinum and Marchandiobasidium aurantiacum. Field Mycology 16:16-17

Healy R, Pfister DH, Rossman AY, Marvanová L, Hansen K (2016) Competing sexual-asexual generic names of Pezizomycetes and recommendations for use. IMA Fungus 7:285-288

Heim R (1957) A propos du Rozites gongylophora A. Möller. Revue Mycologie (Paris) 22:293-299

Hjorstam K, Ryvarden L (2000) Corticioid species (Basidiomycotina, Aphyllophorales) from Colombia II. Mycotaxon 74:241-252

Hjortstam K, Larsson KH, Ryvarden L (1988) The Corticiaceae of North Europe, vol 8. Fungiflora, Oslo

Hofstetter V, Redhead SA, Kauff F, Moncalvo J-M, Matheny PB et al (2014) Taxonomic revision and examination of ecological transitions of the Lyophyllaceae (Basidiomycota, Agaricales) based on a multigene phylogeny. Cryptogamie Mycologie 35:399-425

Holubová-Jechová V (1976) Haplotrichum Link instead of Oidium Link, a necessary nomenclatural change. Česká Mykologie 30:3-4

Holubová-Jechová V (1980) Revision and subdivision of Haplotrichum: anamorphs of Botryobasidium. Mycotaxon 12:122-130

Hong SG, Jung HS (2004) Phylogenetic analysis of Ganoderma based on nearly complete mitochondrial small-subunit ribosomal DNA sequences. Mycologia 96:742-755

Hughes KW, Petersen RH, Johnson JE, Moncalvo J-M, Vilgalys R et al (2001) Infragenic phylogeny of Collybia s. str. based on sequences of ribosomal ITS and LSU regions. Mycological Research 105:164-172

Hughes SJ (1951) Studies on micro-fungi. VII. Allescheriella crocea, Oidium simile, and Pellicularia pruinata. CMI Mycological Papers 41:1-17

Hughes SJ (1958) Revisiones hyphomycetum aliquot cum appendice de nominibus rejiciendis. Canadian Journal of Botany 36:727-836

Hyde KD, Tennakoon DS, Jeewon R, Bhat DJ, Sajeewa SN et al (2019) Fungal diversity notes 1036-1150: taxonomic and phylogenetic contributions on genera and species of fungal taxa. Fungal Diversity 96:1-242 
James TY, Lee M, Diepen LTA (2011) A single mating-type locus composed of homeodomain genes promotes nuclear migration and hterokaryosis in the white-rot fungus Phanerochaete chrysosporium. Eukaryotic Cell 10: 249-261

Johnston PR, Seifert KA, Stone JK, Rossman AY, Maranová L (2014) Recommendations on generic names competing for use in Leotiomycetes (Ascomycota). IMA Fungus 5:91-120

Jülich W (1972) Monographie der Athelieae (Corticiaceae, Basidiomycetes). Willdenowia 7:1-283

Jülich W (1974) The genera of the Hyphodermoideae (Corticiaceae). Persoonia 8: 59-97

Justo A, Miettinen O, Floudas D, Ortiz-Santana B, Sjokvist E et al (2017) A revised family-level classification of the Polyporales (Basidiomycota). Fungal Biology 121:798-824

Kammerer SJ, Burpee LL, Harmon PF (2011) Identification of a new Waitea circinata variety causing basal leaf blight of seashore paspalum. Plant Disease 95:515-522

Kendrick B, Watling R (1979) Mitospores in basidiomycetes. In: Kendrick B (ed) The whole fungus, vol 2, pp 473-545

Kepler RM, Luangsa-ard JJ, Hywel-Jones NL, Quandt CA, Sung G-H et al (2017) A phylogenetic-based nomenclature for Cordycipitaceae (Hypocreales). IMA Fungus 8:335-353

Kersten P, Cullen D (2007) Extracellular oxidative systems of the lignin-degrading basidiomycete Phanerochaete chrysosporium. Fungal Genetics and Biology 44: $77-87$

Kirk P (2020) Index Fungorum. http://www.indexfungorum.org/Names/Names.asp

Kirk PM (2014) Athelia psychrophila (Stalpers \& R.P. de Vries) P.M. Kirk. Index Fungorum 120:1

Kirschner R, Chen C-J (2004) Helicomyxa everyhartioides, a new helicosporous sporodochial hyphomycete from Taiwan with relationships to the Hyaloriaceae (Auriculariales, Basidiomycota). Studies in Mycology 50:337-342

Kirschner R, Chen C-J (2008) A new species of Trimorphomyces (Basidiomycota, Tremellales) from Taiwan. Nova Hedwigia 87:445-455

Kirschner R, Oberwinkler F (2009) Supplementary notes on Basidiopycnis hyalina (Basidiomycota, Atractiellales) and its anamorph. Mycotaxon 109:29-38

Kirschner R, Oberwinkler F, Hofmann TA (2017) A new species of Globulisebacina from Taiwan and new record of Chaetospermum camelliae with Efibulobasidium teleomorph (Sebacinales) from Panama. Nova Hedwigia 105: 329-340

Kirschner R, Sampaio JP, Gadanho M, Weiss M, Oberwinkler F (2001) Cuniculitrema polymorpha (Tremellales, gen. nov. and sp. nov.), a heterobasidiomycete vectored by bark beetles, which is the teleomorph of Sterigmatosporidium polymorphum. Antonie Van Leeuwenhoek 80:149-161

Kirschner R, Yang ZL (2005) Dacryoscyphus chrysochilus, a new staurosporous anamorph with cupulate conidiomata from China and with affinities to the Dacrymycetales (Basidiomycota). Antonie Van Leeuwenhoek 87:329-337

Knudsen $H$, Hansen L (1996) Nomenclatural notes to Nordic macromycetes vol. 1 \& 3. Nordic Journal of Botany 16:211-221

Kotiranta H, Saarenoksa R (2005) Ceratobasidium and Oliveonia (Basidiomycota, Aphyllophorales) in Finland. Annales Botanici Fennici 42:237-245

Koziak ATE, Cheng KC, Thorn RG (2007) Phylogenetic analyses of Nematoctonus and Hohenbuehelia (Pleurotaceae). Canadian Journal of Botany 85:762-773

Kraepelin G, Schulze U (1982) Sterigmatosporidium gen. n., a new heterothallic basidiomycetous yeast, the perfect state of a new species of Sterigmatomyces Fell. Antonie Van Leeuwenhoek 48:471-483

Kreisel H (1972) Pilze aus Pilzgärten von Atta insularis in Kuba. Journal of Basic Microbiology 12:643-654

Kristiansen KA, Taylor DL, Kjøller R, Rasmussen HN, Rosendahl S (2001) Identification of mycorrhizal fungi from single pelotons of Dactylorhiza majalis (Orchidaceae) using single-strand conformation polymorphism and mitochondrial ribosomal large subunit DNA sequences. Molecular Ecology 10:2089-2093

Kwon-Chung KJ (1976) Morphogenesis of Filobasidiella neoformans, the sexual state of Cryptococcus neoformans. Mycologia 68:821-833

Langer G (1994) Die Gattung Botryobasidium Donk (Corticiaceae, Basidiomycetes). Bibliotheca Mycologica 158:1-459

Langer G, Langer E (1998) Haplotrichum parmastii sp. nov. collected in Costa Rica. Folia cryptogamica Estonica 33:63-69

Larsson K-H (1994) Poroid species in Trechispora and the use of calcium oxalate crystals for species identification. Mycological Research 98:1153-1172
Larsson K-H (1995) Taxonomy of Trechispora farinacea and proposed synonyms I. Species with a grandinioid or hydnoid hymenophore. Symbolae Botanicae Upsaliensis 30:101-118

Larsson K-H (2007) Re-thinking the classification of corticioid fungi. Mycological Research 111:1040-1063

Le XT, Le QHN, Pham ND, Duong VH, Dentinger BTM et al (2012) Tomophagus cattienensis sp. nov., a new Ganodermataceae species from Vietnam: evidence from morphology and ITS DNA barcodes. Mycological Progress 11: 775-780

Leal-Dutra CA, Neves MA, Griffith GW, Reck MA, Clasen LA et al (2020) Reclassification of Parapterulicium Corner (Pterulaceae, Agaricales), contributions to Lachnocladiaceae and Peniophoraceae (Russulales) and introduction of Baltazaria gen. nov. MycoKeys 37:39-56

Lee SH, Lee H-O, Park H-S, Ryu HJ, Kim JW, Choi S-H, Park JY, Yang TJ (2019) The complete mitochondrial genome of Wolfiporia cocos (Polyporales: Polyporaceae). Mitochondrial DNA Part B 4(1):1010-1011. https://doi.org/10.1 080/23802359.2018.1524726

Leiner RH, Carling DE (1994) Characterization of Waitea circinata (Rhizoctonia) isolated from agricultural soils in Alaska. Plant Disease 78:385-388

Lemke PA (1964) The genus Aleurodiscus (sensu lato) in North America. Canadian Journal of Botany 42:723-768

Liberta AE (1973) The genus Trechispora (Basidiomycetes, Corticiaceae). Canadian Journal of Botany 51:1871-1892

Linde CC, May TW, Phillips RD, Ruibal M, Smith LM et al (2017) New species of Tulasnella associated with terrestrial orchids in Australia. IMA Fungus 8:27-47

Lindner Czederpiltz DL, Volk TJ, Burdsall HH (2001) Field observations and inoculation experiments to determine the nature of the carpophoroids associated with Entoloma abortivum and Armillaria. Mycologia 93:841-851

Lindner DL, Banik MT (2008) Molecular phylogeny of Laetiporus and other brown rot polypore genera in North America. Mycologia 100:417-430

Link HF (1826) Entwurf eines phytologischen Pflanzensystems nebst einer Anorgnung der Kryptophyten. Abhandlungen der Königlichen Akademie der Wissenschaften zu Berlin 1824:145-194

Liu S-L, Nakasone KK, He S-H (2019) Michenera incrustata sp. nov. (Peniophoraceae, Russulales) from southern China. Nova Hedwigia 108:197-206

Liu X-Z, Wang Q-M, Göker M, Groenewald M, Kachalkin AV et al (2015) Towards an integrated phylogenetic classification of the Tremellomycetes. Studies in Mycology 81:85-147

Lloyd GC (1921) Note 1015 - Aleurodiscus capensis from Rev. J. Rick. Mycological Writings 6:1088.

Lyman GF (1907) Culture studies on the polymorphism of Hymenomycetes. Proceedings of the Boston Society of Natural History 33:125-209 pls. 18-26

Mack J, Assabgui RA, Seifert KA (2021) Taxonomy and phylogeny of the basiomycetous hyphomycete genus Hormomyces. Fungal Systematics and Evolution 7:177-196

Maekawa N (1987) A new species of the genus Cerinomyces. Canadian Journal of Botany 65:583-588

Malysheva V, Spirin V, Miettinen O et al (2019) On Craterocolla and Ditangium (Sebacinales, Basidiomycota). Mycological Progress 18:753-762

Maniotis J (1964) The coprinoid state of Rhacophyllus lilacinus. American Journal Botany 51:485-494

Marek SM, Hansen K, Romanish M, Thorn RG (2009) Molecular systematics of the cotton root rot pathogen, Phymatotrichopsis omnivora. Persoonia 22:63-74

Martin GW (1940) Spore formation in Matula. Journal of the Washington Academy of Science 30:378-382

Martin GW (1942) New or noteworthy tropical fungi-II. Lloydia 5:158-162

Massee G (1888) IV. - On the type of a new order of fungi. Journal of the Royal Microscopical Society of London 1888(2):173-176 PI. IV

Massee G (1898) DCIX Fungi exotici. I. Bulletin of Miscellaneous Information, Royal Gardens, Kew 138:113-136

Matityahu A, Sitruk A, Hadar Y, Belinky PA (2015) Factors affecting the induction of lignin peroxidase in manganese-deficient cultures of the white rot fungus Phanerochaete chrysosporium. Advances in Microbiology 5:83-92

May RC, Stone NRH, Wiesner DL, Bicanic T, Nielsen K (2016) Cryptococcus: from environmental saprophyte to global pathogen. Nature Reviews Microbiology 14:106-117

May TW (2017) Report of the Nomenclature Committee for Fungi: 21 - lists from working groups. Taxon 66:496-499

McCormick MK, Whigham DF, O'Neill J (2004) Mycorrhizal diversity in photosynthetic terrestrial orchids. New Phytologist 63:425-438 
McNabb RFR (1965) Taxonomic studies on the Dacrymycetaceae. New Zealand Journal of Botany 3:223-228

McNabb RFR (1966) Taxonomic studies in the Dacrymycetaceae. VIl. Ditiola Fries. New Zealand Journal of Botany 4:546-558

McNabb RFR (1969) The identity of Hypsilophora. Transactions of the British Mycological Society 52:506-509

McNeill J, Barrie FF, Buck WR, Demoulin V, Greuter W et al (eds) (2012) International Code of Nomenclature for algae, fungi, and plants (Melbourne Code). [Regnum vegetabile no. 154]. Koeltz Scientific Books, Königstein

Mel'nik VA (2011) The first record of Osteomorpha fragilis in Russia. Microbiology 80:582

Middlehoven WJ, Gueho E, de Hoog GS (2000) Phylogenetic position and physiology of Cerinosterus cyanescens. Antonie Van Leeuwenhoek 77:313320

Miettinen O, Larsson K-H (2006) Trechispora elongata species nova from North Europe. Mycotaxon 96:193-198

Miettinen O, Spirin V, Vlasák J, Rivoire B, Stenroos S et al (2016) Polypores and genus concepts in Phanerochaetaceae (Polyporales, Basidiomycota). MycoKeys $17: 1-46$

Miller OK Jr (1969) New species of Pleurotus with a coremioid imperfect stage. Mycologia 61:887-893

Moncalvo J-M, Nilsson RH, Koster B, Dunham SM, Bernauer T et al (2006) The cantharelloid clade: dealing with incongruent gene trees and phylogenetic reconstruction methods. Mycologia 98:937-948

Moncalvo J-M, Vilgalys R, Redhead SA, Johnson JE, James TY et al (2002) One hundred and seventeen clades of euagarics. Molecular Phylogenetics and Evolution 23:357-400

Moore RT (1987) Micromorphology of yeasts and yeast-like fungi and its taxonomic implications. Studies in Mycology 30:203-226

Moraes SRG, Furtado GQ, Scaloppi EAG, Barretp M, Júnior NSM (2006) Esporulação de Erythricium salmonicolor e de Seu Anamorfo Necator decretus, Agente Causal da Rubelose dos Citros no Brasil. Fitopatologia Brasileira 31:519

Motato-Vásquez V, de Mello Gugliotta A, Robledo GL (2015) New records and geographic distribution map of Echinoporia Ryvarden (Schizoporaceae, Basidiomycota) species in the Neotropics. Checklist: The Journal of Biodiversity Data 11:1508

Motato-Vásquez V, Gugliotta AM, Rajchenberg M, Catania M, Urcelay C, Robledo G (2020) New insights on Bjerkandera (Phanerochaetaceae, Polyporales) in the Neotropics with description of Bjerkandera albocinerea based on morphological and molecular evidence. Plant Ecology and Evolution 153: 229-245

Nag Raj TR (1978) Genera coelomycetum. XVI. Fibulocoela form-gen. nov., a coelomycete with basidiomycete affinities. Canadian Journal of Botany 56 : 1485-1491

Nagy LG, Desjardin DE, Vágvölgyi C, Kemp R, Papp T (2013a) Phylogenetic analyses of Coprinopsis sections Lanatuli and Atramentarii identify multiple species within morphologically defined taxa. Mycologia 105:112-124

Nagy LG, Vágvölgyi C, Papp T (2013b) Morphological characterization of clades of the Psathyrellaceae (Agaricales) inferred from a multigene phylogeny. Mycological Progress 12:505-517

Nannfeldt JA (1947) Sphaeronaema rufum Fr., a misunderstood member of Dacrymycetaceae. Svensk Botanische Tidskrift 41:321-338

Nawawi A, Webster J (1982) Sistotrema hamatum sp. nov., the teleomorph of Ingoldiella hamata. Transactions of the British Mycological Society 78:287-291

Noordeloos ME (2009) The genus Deconica (W.G. Sm.) P. Karst. in Europe-new combinations. Österreichische Zeitschrift für Pilzkunde 18:197-199

North RD, Jackson CW, Howse PE (1997) Evolutionary aspects of ant-fungus interactions in leaf-cutting ants. Trends in Ecology \& Evolution 12:386-389

Norvell LL (2008) Report of the nomenclature committee for fungi: 14. Taxon 57: 637-639

Norvell LL (2010) Report of the nomenclature committee for fungi: 15. Taxon 59: 291-293

Núñez M, Ryvarden L (1995) Polyporus (Basidiomycotina) and related genera. [Synopsis Fungorum 10]. Fungiflora, Oslo

Oberwinkler F, Cruz D, Suárez JP (2017) Biogeography and ecology of Tulasnellaceae. In: Tedersoo L (ed) Biogeography of mycorrhizal symbiosis. Ecological Studies 230:237-272

Oberwinkler F, Langer E, Burdsall HH Jr, Tschen J (1990) Heteroacanthella: a new genus in the Tulasnellales. Transactions of the Mycological Society of Japan 31:207-213

Oberwinkler F, Reiss K, Bauer R, Garnica S (2014) Morphology and molecules: the Sebacinales, a case study. Mycological Progress 13:445-470
Oberwinkler F, Riess K, Bauer R, Kirschner R, Garnica S (2013) Taxonomic reevaluation of the Ceratobasidium-Rhizoctonia complex and Rhizoctonia butinii, a new species attacking spruce. Mycological Progress 12:763-776

Olive LS (1957) Tulasnellaceae of Tahiti. A revision of the family. Mycologia 49: 663-679

Ordynets A, Larsson K-H, Langer E (2015) Two new Trechispora species from La Réunion Island. Mycological Progress 14:1-11

Ortiz A, Franco-Molano AE, Bacci M Jr (2008) A new species of Leucoagaricus (Agaricaceae) from Colombia. Mycotaxon 106:371-378

Ostrosina WJ, Garbelotto M (2010) Heterobasidion occidentale sp. nov. and Heterobasidion irregulare nom. nov:: a disposition of North American Heterobasidion biological species. Fungal Biology 114:16-25

Padamsee J, Matheny PB, Dentinger BTM, McLaughlin DJ (2008) The mushroom family Psathyrellaceae: evidence for large-scale polyphyly of the genus Psathyrella. Molecular Phylogenetics and Evolution 46:415-429

Parra LA, Beker H, Grill E, Eberhardt U, Hawksworth DL (2015) (16-18) Proposals to add the unpaginated index of Traité des champignons and two editions of Tabula plantarum fungosarum by J.-J. Paulet to the list of "Suppressed Works" (ICN App. VI). Taxon 64:644-646

Partridge EC, Baker WA, Morgan-Jones G (2001a) Notes on Hyphomycetes. LXXIX. Concerning the Acladium-Alysidium-Haplotrichum complex; nomenclatural and taxonomic considerations, with redescriptions of respective type. Mycotaxon 77:201-214

Partridge EC, Baker WA, Morgan-Jones G (2001b) Notes on Hyphomycetes. LXXXII. A further contribution toward a monograph of the genus Haplotrichum. Mycotaxon 78:127-160

Partridge EC, Baker WA, Morgan-Jones G (2002) Notes on Hyphomycetes. LXXXVL. Some additional Haplotrichum species, with supplementary comments on and a key to the genus. Mycotaxon 82:41-94

Pegler DN (1983) The genus Lentinus. A world monograph. Kew bulletin additional series X. Her Majesty's Stationery Office, London

Pegler DN (2000) Taxonomy, nomenclature and description of Armillaria. In: Fox RTV (ed) Armillaria root rot: biology and control of honey fungus. Intercept, Andover, pp 81-93

Pegler DN, Waterston JM (1968) Heterobasidion annosum. CMI Descriptions of Pathogenic Fungi and Bacteria 192:1-2

Persoon CH (1794) Neuer Versuch einer systematischen Einteilung der Schwämme. Neues Magazin für die Botanik 1:63-128

Persoon CH (1801) Synopsis methodica fungorum. Pars. I \& II. Dietrich, Gottingae

Petch T (1912) Pink disease in Java. The Tropical Agriculturalist and Magazine of the Ceylon Agricultural Society (N.S.) 39:44-45

Petch T (1926) Matula. Transactions of the British Mycological Society 11:67-81

Pildain MB, Rajchenberg M (2013) The phylogenetic position of Postia s.l. (Polyporales, Basidiomycota) from Patagonia, Argentina. Mycologia 105:357-367

Pipolla E, Kotiranta H (2008) The genus Tremella (Basidiomycota, Tremellales) in Finland. Annales Botanici Fennici 45:401-434

Plowright CB (1901) Ozonium auricomum Link. Transactions of the British Mycological Society 1:181-182

Punja ZK (1985) The biology, ecology, and control of Sclerotium rolfsii. Annual Review of Phytopathology 23:97-127

Quandt CA, Kepler RM, Gams W, Araújo JPM, Ban S et al (2014) Phylogeneticbased nomenclatural proposals for Ophiocordycipitaceae (Hypocreales) with new combinations in Tolypocladium. IMA Fungus 5:121-134

Rader WE (1948) Rhizoctonia carotae n.sp. and Gliocladium aureum n.sp., two new root pathogens of carrots in cold storage. Phytopathology 38:440-452

Rafinesque CS (1819) Prodrome. Des nouveaux Genres de Plantes observés en 1817 et 1818 dans l'intérieurs des États-Unis d'Amerique. Journal de Physique, de Chimie, d'Histoire Naturelle et des Arts 89:96-107

Rafinesque CS (1830) Medical flora, or, Manual of the medical botany of the United States of North America, vol 2. Atkinson \& Alexander, Philadelphia

Rajchenberg M, Robledo G (2013) Pathogenic polypores in Argentina. Forest Pathology 43:171-184

Rajchenberg M, Robledo GL (2005) Aleurocystis gloeocystidia sp. nov. on Polylepis australis in Argentina. Mycotaxon 92:317-322

Rant A (1911) De djamoer oepas-ziekte in het algemeen en hij kina in het bijzonder. Mededeelingen uitgaande van het Departement van Landbouw. G. Kolff \& Co, Batavia

Rant A (1912) Uber die djamoer-oepas-Krankheit und uber das Corticium javanicum Zimm. Bulletin du Jardin Botanique de Buitenzorg 4:1-50

Réblová M, Miller AN, Rossman AY, Seifert KA, Crous PW (2016) Recommendations for competing sexual-asexually typified generic names in 
Sordariomycetes (except Diaporthales, Hypocreales, and Magnaporthales). IMA Fungus 7:131-153

Redhead S, Seifert KA, Vilgalys R, Moncalvo J-M (2000) Rhacophyllus and Zerovaemyces. Teleomorphs or anamorphs? Taxon 49:789-798

Redhead SA (2016) Nomenclature novelties. Index Fungorum no. 315

Redhead SA, Ginns J (1985) A reappraisal of agaric genera associated with briown rots of wood. Transactions of the Mycological Society of Japan 26:349-381

Redhead SA, Ginns J (2006) (1738) Proposal to conserve the name Poria cocos against Daedalea extensa (Basidiomycota). Taxon 55:1027-1028

Redhead SA, Moncalvo JM, Vilgalys R, Matheny MB, Guzmán-Dávalos PB et al (2007) Proposal to conserve the name Psilocybe (Basidiomycota) with a conserved type. Taxon 56:255-257

Redhead SA, Seifert KA (2001a) Asterophora Ditmar ex Link 1809 versus Nyctalis Fries 1825, and the status of Ugola Adanson 1763. Taxon 50:243-268

Redhead SA, Seifert KA (2001b) Proposal to conserve the name Agaricus lycoperdoides Bull. (E Asterophora lycoperdoides (Bull.) Ditmar) against Asterophora agaricoides Fr.:Fr. and Asterophora lycoperdoides Fr.:Fr. Taxon 50:279-280

Redhead SA, Vilgalys R, Moncalvo J-M, Johnson J, Hopple JS Jr (2001a) Coprinus Pers. and the disposition of Coprinus species sensu lato. Taxon 50:203-241

Redhead SA, Vilgalys R, Moncalvo J-M, Johnson J, Hopple JS Jr (2001 b) (14731474) Proposals to conserve the name Psathyrella (Fr.) Quel. with a conserved type and to reject the name Pselliophora P. Karst. (Basidiomycetes: Psathyrellaceae). Taxon 50:275-277

Remsberg RE (1940) Studies in the genus Typhula. Mycologia 32:52-96

Roberts P (1994a) Long-spored Tulasnella species from Devon, with additional notes on allantoid-spored species. Mycological Research 98:1235-1244

Roberts P (1994b) Globose and ellipsoid-spored Tulasnella species from Devon and Surrey, with a key to the genus in Europe. Mycological Research 98:1431-1452

Roberts P (1998) Oliveonia and the origin of the holobasidiomycetes. Folia Cryptogamica Estonica 33:127-132

Roberts P (1999) Rhizoctonia-forming fungi. A taxonomic guide. Kew Botanic Gardens, Kew

Robledo GL, Palacio M, Urcelay C, Vasco-Palacios AM, Crespo E et al (2020) Mystery unveiled: Diacanthodes Singer - a lineage within the core polyporoid clade. Systematics and Biodiversity 18:538-556

Rogers DP (1933) A taxonomic review of the Tulasnellaceae. Annales Mycologici 31:191-203

Rossman AY, Adams GC, Cannon PF, Castlebury LA, Crous PW et al (2015a) Recommendations of generic names in Diaporthales competing for protection or use. IMA Fungus 6:145-154

Rossman AY, Allen WC, Braun U, Castlebury LA, Chaverri P et al (2016a) Overlooked competing asexual and sexually typified generic names of Ascomycota with recommendations for their use or protection. IMA Fungus 7:289-308

Rossman AY, Allen WC, Castlebury LA (2016b) New combinations of plant-associated fungi resulting from the change to one name for fungi. IMA Fungus 7:1-7

Rossman AY, Crous PW, Hyde KD, Hawksworth D, Aptroot A et al (2015b) Recommended names of pleomorphic genera in Dothideomycetes. IMA Fungus 6:507-523

Rossman AY, Seifert KA, Samuels GJ, Minnis AM, Schroers H-J et al (2013) Genera in Bionectriaceae, Hypocreaceae, and Nectriaceae (Hypocreales) proposed for acceptance or rejection. IMA Fungus 4:41-51

Roux J, Coetzee MPA (2005) First report of pink disease on native trees in South Africa and phylogenetic placement of Erythricium salmonicolor in the Homobasidiomycetes. Plant Disease 89:1158-1163

Ruiz EF, Molinari-Novoa EA (2016) Notulae nomenclaturales VI. The dismissal of Coccobotrys (anamorphic Agaricaceae). Weberbauerella. A journal on botanical curiosities 1(16): 1-4

Rungjindamai N, Sakayaroj J, Plaingam N, Somrithipol S, Jones EBG (2008) Putative teleomorphs of the coelomycete genera Chaetospermum, Guilia and Mycotribulus based on nuclear large and small subunit rDNA. Mycological Research 112:802-810

Ryker TC, Gooch FS (1938) Rhizoctonia sheath spot of rice. Phytopathology 28 : $233-246$

Ryvarden L (1983) Type studies in the Polyporaceae 14. Species described by N. Patouillard either along or with other mycologists. Occasional Papers of the Farlow Herbarium of Cryptogamic Botany 18:1-39

Ryvarden L (1998) The genus Aleurocystis. Cryptogamie Mycologie 19:93-97

Ryvarden L, Johansen I (1980) A preliminary polypore Flora of East Africa. Fungiflora, Oslo

Saccardo PA (1916) Hymeniales ceterae Agaricaceae, Polyporaceae, Hydnaceae, Thelephoraceae, Tremellaceae. Flora Italica Cryptogama Fungi 1:577-1386
Samson RA, Visagie CM, Houbraken J, Hong S-B, Hubka V et al (2014) Phylogeny, identification and nomenclature of the genus Aspergillus. Studies in Mycology 78:141-173

Seifert KA (1985) A monograph of Stilbella and some allied Hyphomycetes. Studies in Mycology 27:1-234

Seifert KA (2013) Pionnotes, a synonym of Dacrymyces rather than Fusarium. Mycotaxon 123:205-211

Sharon M, Kuninaga S, Hyakumachi M, Sneh B (2006) The advancing identification and classification of Rhizoctonia spp. using molecular and biotechnological methods compared with the classical anastomosis grouping. Mycoscience 47:299-316

Shear CL (1907) New species of fungi. Bulletin of the Torrey Botanical Club 34:305-317

Shen L-L, Liu H-X, Cui B-K (2015) Morphological characters and molecular data reveal two new species of Postia (Basidiomycetes) from China. Mycological Progress 14:1-8

Shen LL, Wang M, Zhou JL, Xing JH, Cui BK et al (2019) Taxonomy and phylogeny of Postia. Multigene phylogeny and taxonomy of the brown-rot fungi: Postia (Polyporales, Basidiomycota) and related genera. Persoonia 42: 101-126. https://doi.org/10.3767/persoonia.2019.42.05

Shevchenko MV (2018) The first record of Postia ptychogaster (Polyporales, Fomitopsidaceae) in Ukraine. Chornomorski Botanical Journal 14:91-97

Shirouzu T, Fukasawa Y, Nakamura Y (2017) Femsjonia uniseptata (Dacrymycetes, Basidiomycota), a new species collected from Pinus densiflora forests in Japan. Phytotaxa 312:2

Shirouzu T, Hirose D, Oberwinkler F, Shimomura N, Maekawa N et al (2013) Combined molecular and morphological data for improving phylogenetic hypothesis in Dacrymycetes. Mycologia 105:1110-1125

Shirouzu T, Hirose D, Tokumasu S (2007) Sequence analyses of the 285 rRNA gene D1/D2 region suggest Dacrymyces (Heterobasidiomycetes, Dacrymycetales) is polyphyletic. Mycoscience 48:388-394

Shirouzu T, Hirose D, Tokumasu S (2009) Taxonomic study of the Japanese Dacrymycetes. Persoonia 23:16-34

Singer R (1948) Diagnoses fungorum novorum Agaricalium. Sydowia 2:26-42

Singer R (1970) Omphalinae (Clitocybeae-Tricholomataceae Basidiomycetes). Flora Neotropica 3:1-84

Smith AL, Ramsbottom J (1914) New or rare fungi. Transactions of the British Mycological Society 4:318-330

Stadler M, Kuhnert E, Peršoh D, Fournier J (2013) The Xylariaceae as model example for a unified nomenclature following the "one fungus-one name" (1F1N) concept. Mycology 4:5-21

Stafleu FA, Cowan RS (1976) Taxonomic literature. A selective guide to botanical publications and collections with dates, commentaries and types, vol 1: A-G, 2nd edn. Bohn, Scheltema \& Holkema, Utrecht

Stalpers JA (1974) Spiniger, a new genus for imperfect states of basidiomycetes. Proceedings of the Koninklijke Nederlandse Akademie van Wetenschappen, C 77:402-407

Stalpers JA (1984) A revision of the genus Sporotrichum. Studies in Mycology 24:1-105

Stalpers JA (2000) The genus Ptychogaster. Karstenia 40:167-180

Stalpers JA, Andersen TF (1996) A synopsis of the taxonomy of teleomorphs connected with Rhizoctonia s. I. In: Sneh B et al (eds) Rhizoctonia species, taxonomy, molecular biology, ecology, pathology and disease control. Kluwer Academic Publishers, Dordrecht, pp 49-63

Stalpers JA, Andersen TF, Gams W (1998) Two proposals to conserve the names Rhizoctonia and R. solani (Hyphomycetes). Taxon 47:725-726

Stalpers JA, Seifert KA, Samson RA (1991) A revision of the genera Antromycopsis, Sclerostilbum, and Tilachlidiopsis (Hyphomycetes). Canadian Journal of Botany 69:6-15

Stalpers JA, Vlug I (1983) Confistulina, the anamorph of Fistulina hepatica. Canadian Journal of Botany 61:1660-1666

Sumstine DR (1911) Studies in North American Hyphomycetes I. The genera Rhinotrichum and Olpitrichum. Mycologia 3:45-56

Surmont I, Van Aelst F, Verbanck J, De Hoog GS (2002) A pulmonary infection caused by Coprinus cinereus (Hormographiella aspergillata) diagnosed after a neutropenic episode. Medical Mycology 40:217-219

Tangthirasunun N, Silar P, Bhat DJ, Chukeatirote E, Wikee S et al (2014) Morphology and phylogeny of Chaetospermum (asexual coelomycetous Basidiomycota). Phytotaxa 175(1):061-072

Thorn RG (2013) Nomenclatural novelties: Hohenbuehelia. Index Fungorum 16:1-2 (ISSN 2049-2375)

Thorn RG, Barron GL (1984) Carnivorous mushrooms. Science 224:76-78

Toda T, Hayakawa T, Mghalu JM, Yaguchi S, Hyakumachi M (2007) A new Rhizoctonia sp. closely related to Waitea circinata causes a new disease of creeping bentgrass. Journal of General Plant Pathology 73:379-387 
Toda T, Mushika T, Hayakawa T, Tanaka A, Tani T et al (2005) Brown ring patch: a new disease on bentgrass caused by Waitea circinata var. circinata. Plant Disease 89:536-542

Tubaki K (1976) Cultural and taxonomical studies on Hormomyces aurantiacus. Transactions of the Mycological Society of Japan 17:243-247

Turland NJ, Wiersema JH, Barrie FR, Greuter W, Hawksworth DL et al (eds) (2018) International Code of Nomenclature for algae, fungi, and plants (Shenzhen Code) adopted by the Nineteenth International Botanical Congress Shenzhen, China, July 2017. Regnum Vegetabile 159. Koeltz Botanical Books, Glashütten. https://doi.org/10.12705/Code.2018

Tzean SS, Estey RH (1991) Geotrichopsis mycoparasitica gen. et sp. nov. (Hyphomycetes), a new mycoparasite. Mycological Research 95:1350-1354

Valenzuela E, Garnica S (2000) Pseudohelicomyces, a new anamorph of Psilocybe. Mycological Research 104:738-741

Vampola P, Ordynets A, Vlasak J (2014) The identity of Postia lowei (Basidiomycetes, Polyporales) and notes on related and similar species. Czech Mycology 66:39-52

van Bambeke C (1900) Le Coccobotrys xylophilus (Fr.) Boud. et Pat. (= Cenococcus xylophilum Fr.) est le mycélium du Lepiota meleagis (Sow.) Sacc. Bulletin de la Société Royale de Botanique de Belgique 39:81-84

Vellinga EC (2000) Notes on Lepiota and Leucoagaricus. Type studies on Lepiota magnispora, Lepiota barssii, and Agaricus americanus. Mycotaxon 76:429-438

Vellinga EC, Sysouphanthong P, Hyde KD (2011) The family Agaricaceae: phylogenies and two new white-spored genera. Mycologia 103:494-509

Vilgalys R, Cubeta MA (1994) Molecular systematics and population biology of Rhizoctonia. Annual Review of Phytopathology 32:135-155

Visagie CM, Houbraken J, Frisvad JC, Hong S-B, Klaassen CHW et al (2014) Identification and nomenclature of the genus Penicillium. Studies in Mycology 78:343-371

Vizzini A, Zotti M (2008) Postia ptychogaster, an unusual two-stage polypore new to Italian mycobiota. Mycotaxon 103:319-318

Vlasenko VA, Vlasenko AV, Zmitrovich IV (2017) First record of Neolentinus lepideus f. ceratoides (Gloeophyllales, Basidiomycota) in Novosibirsk region. Current Research in Environmental and Applied Mycology 7:187-192

Vojvodić M, Tanovic B, Mitrovic P, Vico I, Bulajic A (2020) Waitea circinata var. zeae causing root rot of cabbage and oilseed rape. Plant Disease Published Online: 14 Oct 2020. https://doi.org/10.1094/PDIS-05-20-0942-RE

Vu D, Groenewald M, de Vries M, Gehrmann T, Stielow B et al (2019) Large-scale generation and analysis of filamentous fungal DNA barcodes boosts coverage for kingdom fungi and reveals thresholds for fungal species and higher taxon delimitation. Studies in Mycology 92:135-154

Walker J (1996) An opinion on the validity of the generic name Postia Fries 1874 (Eumycota) Aphyllophorales. Australasian Mycological Newsletter 15:23-25

Wang K, He X, Zhao C-L (2020) Scytinostroma yunnanense sp. nov. (Russulales, Basidiomycota) evidenced by morphological characteristics and phylogenetic analyses in China. Phytotaxa 451(2):145-153

Wang Y-Z, Zhang J, Yan-Li Z, Tao L, Tao S et al (2013) Mycology, cultivation, traditional uses, phytochemistry and pharmacology of Wolfiporia cocos (Schwein.) Ryvarden et Gilb.: a review. Journal of Ethnopharmacology 147:265-276

Warcup JH, Talbot PHB (1962) Ecology and identity of mycelia isolated from soil. Transactions of the British Mycological Society 45:495-518

Warcup JH, Talbot PHB (1967) Perfect states of rhizoctonias associated with orchids. III. New Phytologist 66:631-641

Watling R (1974) Dimorphism in Entoloma arbortivum. Bulletin mensuel de la Socie'te' linne'enne de Lyon 43:449-470

Watling R (1979) The morphology, variation and ecological significance of anamorphs in the Agaricales. In: Kendrick B (ed) The whole fungus, vol 2 National Museum of Natural Sciences, National Museums of Canada. The Kananaskis Foundation, Ottawa, pp 453-469

Watling R, Kendrick B (1979) Osteomorpha Arnaud -a validation. Naturalist 104:1-4

Weiss M, Oberwinkler F (2001) Phylogenetic relationships in Auriculariales and related groups-hypotheses derived from nuclear ribosomal DNA sequences. Mycological Research 105:403-415

Weiss M, Selosse MA, Rexer KH, Urban A, Oberwinkler F (2004) Sebacinales: a hitherto overlooked cosm of heterobasidiomycetes with a broad mycorrhizal potential. Mycological Research 108:1003-1010

Wells K, Bandoni RJ (2001) Heterobasidiomycetes. In: McLaughlin DJ, McLaughlin EG, Lemke PA (eds) The Mycota. Vol. VII Part B. Systematics and evolution. Springer-Verlag, Berlin, pp 85-120

Wiersema JH, Turland NJ, Barrie FR, Greuter W, Hawksworth DL, Herendeen PS, Knapp S, Kusber W-H, Li D-Z, Marhold K, May TW, McNeill J, Monro AM,
Prado J, Price MJ, Smith GF (eds) (2020) International Code of Nomenclature for algae, fungi, and plants (Shenzhen Code) adopted by the Nineteenth International Botanical Congress Shenzhen, China, July 2017: Appendices IVII. Continuously updated online at https://naturalhistory2.si.edu/botany/ codes-proposals/. Accessed 13 Jan 2020

Wijayawardene DNN, McKenzie EHC, Hyde KD (2012) Towards incorporating anamorphic fungi in a natural classification - checklist and notes for 2011. Mycosphere 3:157-228

Wu F, Li S-J, Dong C-H, Dai Y-C, Papp V (2020) The genus Pachyma (syn. Wolfiporia) reinstated and species clarification of the cultivated medicinal mushroom "Fuling" in China. Frontiers in Microbiology 11:590788

Xu Z, Harrington TC, Gleason ML, Batzer JC (2010) Phylogenetic placement of plant pathogenic Sclerotium species among teleomorph genera. Mycologia 102:337-346

Yang CS, Korf RP (1985) Ascorhizoctonia gen. nov. and Complexipes emend., two genera for anamorphs of species assigned to Tricharina (Discomycetes). Mycotaxon 23:457-481

Zamora JC, Ekman S (2019) Phylogeny and character evolution in the Dacrymycetes, and systematics of Unilacrymaceae and Dacryonaemataceae fam. nov. Persoonia - Molecular Phylogeny and Evolution of Fungi 44:161-205

Zamora JC, Ekman S (2020) Phylogeny and character evolution in the Dacrymycetes, and systematics of Unilacrymaceae and Dacryonaemataceae fam nov. Persoonia 4:161-205

Zamora JC, Perez-Ortega S, Rico VJ (2014) Heteroacanthella ellipsospora sp. nov., the first lichenicolous basidiomycete with acanthoid basidia. The Lichenologist 46:17-23

Zervakis Gl, Moncalvo J-M, Vilgalys R (2004) Molecular phylogeny, biogeography and speciation of the mushroom species Pleurotus cystidiosus and allied taxa. Microbiology 150:715-726

Zhang N, Luo J, Rossman A, Aoki T, Chuma I et al (2016) Generic names in Magnaporthales. IMA Fungus 7:155-159

Zhou L-W, Qin W-M (2013) Sistotrema subconfluens sp. nov. (Cantharellales, Basidiomycota) from Changbaishan Nature Reserve, northeastern China. Mycoscience 54:178-182

\section{Publisher's Note}

Springer Nature remains neutral with regard to jurisdictional claims in published maps and institutional affiliations.
Ready to submit your research? Choose BMC and benefit from:

- fast, convenient online submission

- thorough peer review by experienced researchers in your field

- rapid publication on acceptance

- support for research data, including large and complex data types

- gold Open Access which fosters wider collaboration and increased citations

- maximum visibility for your research: over $100 \mathrm{M}$ website views per year

At BMC, research is always in progress.

Learn more biomedcentral.com/submissions 